\title{
An Updated List of Neuromedicinal Plants of Pakistan, Their Uses, and Phytochemistry
}

\author{
Abdul Waheed Khan $\left(\mathbb{D},{ }^{1}\right.$ Arif-ullah Khan $\left(\mathbb{D},{ }^{2}\right.$ Syed Muhammad Mukarram Shah, ${ }^{3}$ \\ Aziz Ullah, ${ }^{4}$ Muhammad Faheem $\left(\mathbb{B}^{,}{ }^{2}\right.$ and Muhammad Saleem ${ }^{2}$ \\ ${ }^{1}$ Department of Pharmacy, University of Lahore, Islamabad, Pakistan \\ ${ }^{2}$ Riphah Institute of Pharmaceutical Sciences, Riphah International University, Islamabad, Pakistan \\ ${ }^{3}$ Department of Pharmacy, University of Swabi, Khyber Pakhtunkhwa, Pakistan \\ ${ }^{4}$ Department of Pharmacy, Forman Christian College, Lahore, Pakistan \\ Correspondence should be addressed to Arif-ullah Khan; arif.ullah@riphah.edu.pk
}

Received 12 November 2018; Revised 14 January 2019; Accepted 5 February 2019; Published 3 March 2019

Guest Editor: José C. T. Carvalho

\begin{abstract}
Copyright (C) 2019 Abdul Waheed Khan et al. This is an open access article distributed under the Creative Commons Attribution License, which permits unrestricted use, distribution, and reproduction in any medium, provided the original work is properly cited.
\end{abstract}

Background. Almost every region of Pakistan is stacked with a large number of medicinal plants. Due to high cost and unavailability of allopathic medicines for the neurological diseases, especially in rural areas, traditional healers prescribe phytotherapy for various neurological diseases like epilepsy, depression, anxiety, insomnia, Alzheimer, and migraine. Such treatments are considered to be most effective by the native people. Methods. The data was collected from articles published on medicinal plants of various districts of Pakistan, using article search engines like Medline, Pubmed, Web of Science, Science Direct, and Google Scholar. Also, information regarding various neurological uses and mode of applications of medicinal plants was obtained from traditional healers, folk medicine users, and local elderly people having knowledge of medicinal plants. Results. A total of 54 families were found to be used in various neurological diseases, of which the highest use was of Solanaceae (22.22\%), Asteraceae (12.96\%), Lamiaceae, Papaveraceae, and Poaceae, 9\% each, and Caprifoliaceae, Cucurbitaceae, Rhamnaceae, and Rosaceae, 5.5\% each. According to districts, $15 \%$ of plants that were effective in neurological affections were found in Bahawalpur, $11 \%$ in Swat, $8 \%$ in Muzaffarabad, 7\% in Malakand, and 6\% in Bahawalnagar, Dir, Gilgat, and Sarghoda each, with 5\% in Dera ghazi khan and Jhelum each. According to the plant's habit, out of total of 103 plants, $61.15 \%$ were found to be herbs, $22.33 \%$ trees, $11.65 \%$ shrubs, and $4.85 \%$ climbers. According to the part used of plant, whole plant, leaves, fruits, roots, seeds, and flowers were found to be used $32.03 \%, 24.27 \%$, $20.38 \%, 16.50 \%, 13.59 \%$, and $11.65 \%$, respectively. According to disease's types, $45.63 \%$ were found to be effective in insomnia, $31.06 \%$ in epilepsy $12.62 \%$ in depression, $6.80 \%$ in anxiety, $7.77 \%$ in hysteria, and $5.88 \%$ in migraine. Conclusion. Taking into consideration this useful knowledge on medicinal properties of the plants for curing neurologic diseases, it is believed that research in areas of ethnomedicine and ethnopharmacology can bring auspicious results that have potential of adding value to the very rich natural resources of Pakistan. This study will help all the researchers from diverse backgrounds working on plants based medicine for neurological diseases.

\section{Introduction}

Globally, neurological diseases are among the major contributors to mortality and morbidity, particularly in developing nations. The well-known manifestations of neurological diseases include mood swing, restlessness, hopelessness, poor coordination, seizures, impaired cognition, paralysis, distress of sensation, muscle weakness, pain, and confusion [1]. There are more than six hundred neurological diseases, some of which are relatively common and well known while others are rare or poorly recognized [2]. Demographic, socioeconomic, and geographic conditions are the major factors affecting epidemiology of neurological diseases. Globally, the overall burden of neurological diseases is about $6.5 \%$. In lower income countries, neurological diseases range from 4 to $5 \%$, as compared to high income countries where such diseases 
TABLE 1: Global epidemiology of neurological diseases and theircomparative prevalence in Pakistan and neighboring countries.

\begin{tabular}{|c|c|c|c|c|c|c|c|}
\hline & Migraine & Stroke & Epilepsy & Depression & Anxiety & Parkinson & Alzheimer \\
\hline Worldwide & $14.9 \%$ [49] & $5 \%[50]$ & $0.5-1 \%[51]$ & $4.4 \%[52]$ & $3.6 \%[52]$ & $1 \%[53]$ & $11.2 \%[54]$ \\
\hline Asia & $9.1 \%[55]$ & $0.94 \%[56]$ & $0.49 \%[57]$ & $4.4 \%[52]$ & $2.8 \%[58]$ & $0.63 \%[59]$ & $1.9 \%[54]$ \\
\hline Africa & $5.61 \%[60]$ & $0.4 \%[61]$ & $1.13 \%[62]$ & $5.2 \%[52]$ & $4.4 \%[52]$ & $0.44 \%[63]$ & $1.6 \%[54]$ \\
\hline North America & $14.4 \%[64]$ & $2.7 \%[65]$ & $0.8 \%[66]$ & $10.6 \%[67]$ & $7.7 \%[58]$ & $1.3 \%$ [59] & $6.4 \%[54]$ \\
\hline South America & $11.6 \%[64]$ & $0.7 \%[68]$ & $0.98 \%[57]$ & $13.8 \%[67]$ & $10.4 \%[69]$ & $2.3 \%[59]$ & $4.6 \%[54]$ \\
\hline Europe & $15 \%[70]$ & $6.25 \%[71]$ & $0.82 \%[62]$ & $4.2 \%[52]$ & $3.9 \%[52]$ & $1.6 \%[72]$ & $4.4 \%[54]$ \\
\hline Australia & $6 \%[73]$ & $1.8 \%[74]$ & $0.44 \%[75]$ & $5.9 \%[52]$ & $7 \%[52]$ & $0.46 \%[76]$ & $6.4 \%[77]$ \\
\hline Pakistan & $26.1 \%[78]$ & $0.25 \%[79]$ & $2 \%[4]$ & $4.2 \%[52]$ & $3.5 \%[52]$ & $0.23 \%[51]$ & $1 \%[4]$ \\
\hline India & $25.2 \%[51]$ & $3.69 \%[71]$ & $0.39 \%[80]$ & $4.5 \%[52]$ & $3.0 \%[52]$ & $0.07 \%[81]$ & $1.91 \%[82]$ \\
\hline Iran & $14 \%[51]$ & $0.36 \%[51]$ & $1.8 \%[80]$ & $4.9 \%[52]$ & $4.6 \%[52]$ & $0.29 \%[83]$ & $2.3 \%[84]$ \\
\hline China & $9.3 \%$ [78] & $4.3 \%[71]$ & $0.3 \%[80]$ & $4.2 \%[52]$ & $3.1 \%[52]$ & $1.7 \%$ [85] & $3.21 \%[85]$ \\
\hline Afghanistan & $0.9 \%[86]$ & $5.2 \%[87]$ & $8.9 \%[88]$ & $51.8 \%$ [89] & $38.5 \%$ [89] & $35.4 \%[90]$ & $15.3 \%$ [91] \\
\hline
\end{tabular}

range from 10 to $11 \%$. This high ratio of neurological diseases in advanced countries may be due to their more advanced public health system and health-related facilities that provide and maintain complete data of their patients [1].

About 45 million people of the world, above 18 years of age, suffer from schizophrenia at some stage of their lives, 340 million are affected by depression, and both these diseases are accountable for $60 \%$ of all suicides, while Alzheimer and epilepsy affect about 11 and 45 million people, respectively, around the world accounting for $1 \%$ of the total disease burden in the world [3].

In Pakistan, about $10 \%$ people suffer from mental diseases, representing a foggy picture with $2 \%$ prevalence of' epilepsy, $5 \%$ depression, $1 \%$ Alzheimer, and $1.5 \%$ schizophrenia [4] as shown in (Table 1). These mental morbidities are responsible for high suicidal rate. Major factors contributing to this alarming increase in mental diseases are unemployment, poverty, political unreliability, violence, and other social horrors and evils beyond the genetic and biological susceptibility [5].

Medicinal plants have been used from the very beginning in health care systems. Studies have been carried out globally to verify their efficacy and some of the findings have led to the production of plant-based medicines. Due to limited access to modern medicine, the local population uses medicinal plants to treat most diseases $[6,7]$. Recent focus on plant research has increased worldwide and most evidence has been collected to determine the immense potential of medicinal plants [8]. Medical plants have therapeutic benefits and fewer side effects in comparison with synthetic drugs [9]. Drugs used for neurological diseases along with their side effects are given in (Table 2).

Herbs may provide a source of new compounds including many drugs that are derived from plant sources. For several neurological diseases, modern medicine offers symptomatic treatment that is often expensive and associated with side effects. Indian system of medicine has traditionally been used in several neurological conditions. The accessibility, cost effectiveness, and lower incidence of side effects of plant products offer considerable advantages [10].
Various plant extracts have been screened and investigated for their potential neuropharmacological activities in different experimental models of animals comprising mice and rats. Herbal extracts and natural products including Bacopa monnieri, Cannabis sativa, Solanum nigrum, Withania somnifera, Papaver somniferum, Zizyphus jujube, Tribulus terrestris, and Verbena officinalis showed different neuropharmacological activities. These agents can be used alone or as adjuncts to standard drugs, used for various neurological diseases like depression, epilepsy, schizophrenia, Alzheimer, Parkinson, hysteria, melancholia, and dementia, for increasing their efficacy and decreasing side effects.

In developing countries, plant-based medicines are being used by $75-80 \%$ of population [11]. The knowledge of indigenous medicinal plants is a part of Pakistani culture and traditionally, majority of Pakistani people use herbal medicines for various diseases [12].

In Pakistan, folk medicines have more use in rural and less developed areas for the treatment of various diseases because of easy access, cost effectiveness, less side effects, and unavailability of allopathic therapeutic agents [13]. This type of treatment, using traditional medicinal flora, is practiced regularly in homes and transferred from generation to generation as a cultural virtue. However, this tradition and associated knowledge are diminishing rapidly due to negligence and less interest of new generation to receive this gift of ethnomedicinal prosperity from their ancestors. Various parameters like industrialization, migration from rural to urban areas for education and jobs, passion towards advanced lifestyles, deforestation, and allopathic medicine might have brought this change in behavior. Therefore, before it is lost forever, this valuable traditional knowledges need to be urgently collected and systematically documented for the interest of humanity [14].

\section{Materials and Methods}

First the articles published on the medicinal plants of various districts of Pakistan were searched in online research database, i.e., Medline, PubMed, Web of Science, Science 


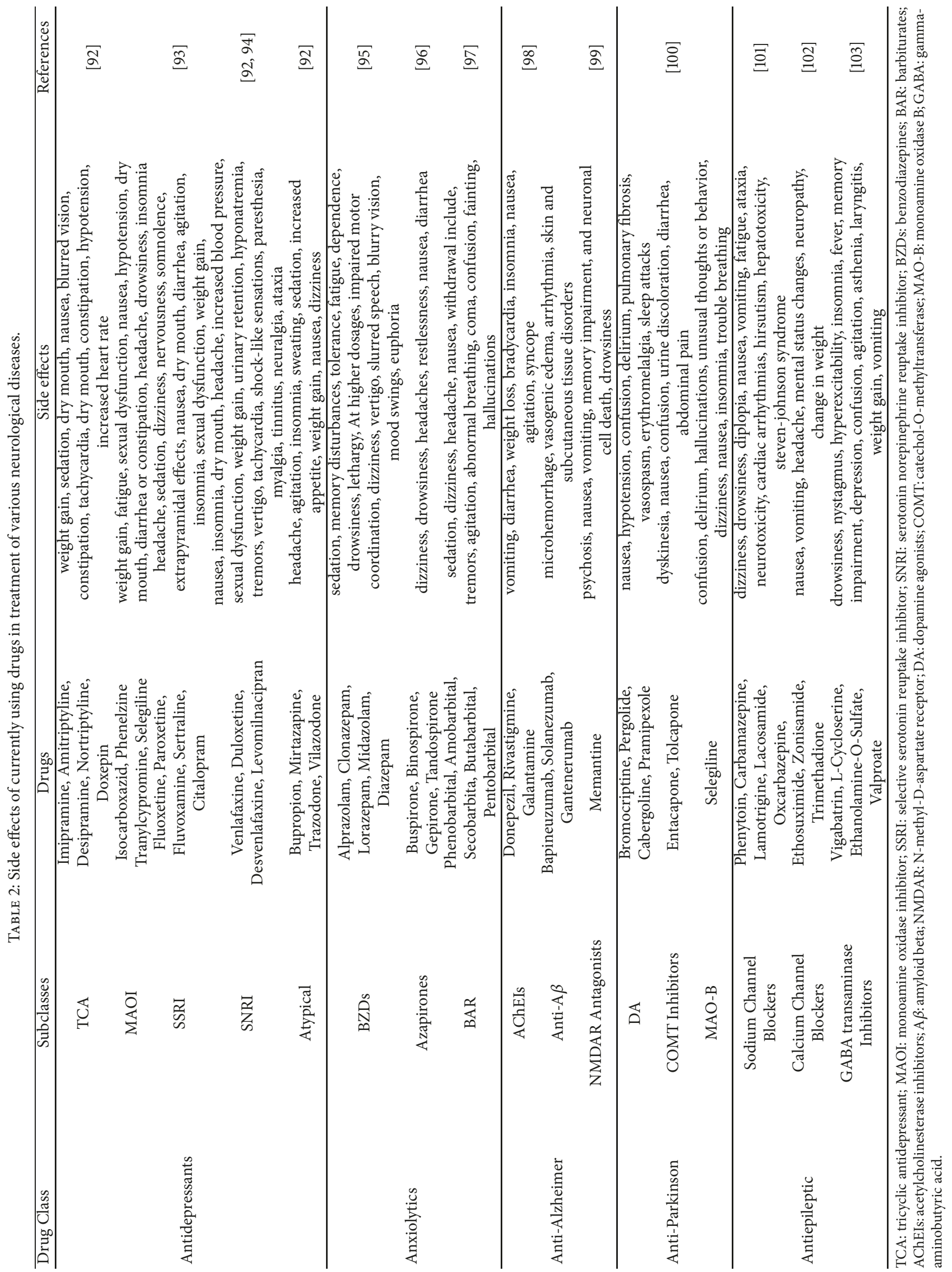




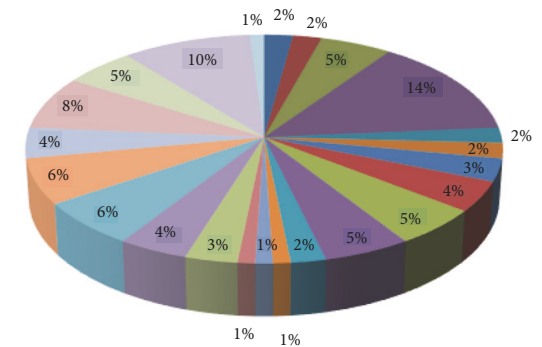

- Attock

- Azad Jammu \& Kashmir

- Bahawalnagar

- Bahawalpur

- Bannu

- Battagram

- Buner

- Dera Ghazi Khan

- Dir

- Gilgit

- Gujrat

- Hafizabad

Figure 1: District-wise percentage of plants used for neurological diseases.

Direct, and Google Scholar, by using special key words "medicinal plants", herbal plants, neurological diseases, specific districts names, antialzheimer, antiparkinson, antidepression, sedative, anxiolytic, antiepileptics, epidemiology, and prevalence, from January to March 2018, and downloaded. These entire articles were then viewed and the data of medicinal plants, which have neurological effects, were collected and tabulated in (Table 3). We have personally visited districts Bahawalpur, Bannu, Buner, Dir, Gilgat, Islamabad, Jhelum, Malakand, Mianwali, Rawalpindi, Sargodha, and Swat in April-June 2018 and collected information regarding plants local names, local use, mode of applications, and administration of these plants in neurological diseases from local traditional healers, folk medicine users, and local elderly people of those districts having knowledge of medicinal plants. Information was also collected from distant districts with the help of friends living there via social media (phone calls, text messages, WhatsApp calls and messages, and emails).

\section{Results and Discussion}

A total of 54 families were found to be useful in various neurological diseases, of which the highest use was of Solanaceae (22.22 \%), Asteraceae (12.96 \%), Lamiaceae, Papaveraceae, and Poaceae, $9 \%$ each, and Caprifoliaceae, Cucurbitaceae, Rhamnaceae, and Rosaceae, $5.5 \%$ each (Table 3). As per district point of view, $15 \%$ plants, effective in neurological affections, were found in Bahawalpur, $11 \%$ in Swat, $8 \%$ in Muzaffraabad, $7 \%$ in Malakand, and $6 \%$ in Bahawalnagar, Dir, Gilgat, and Sarghoda each, with 5\% in Dera ghazi khan and Jhelum each (Figure 1).

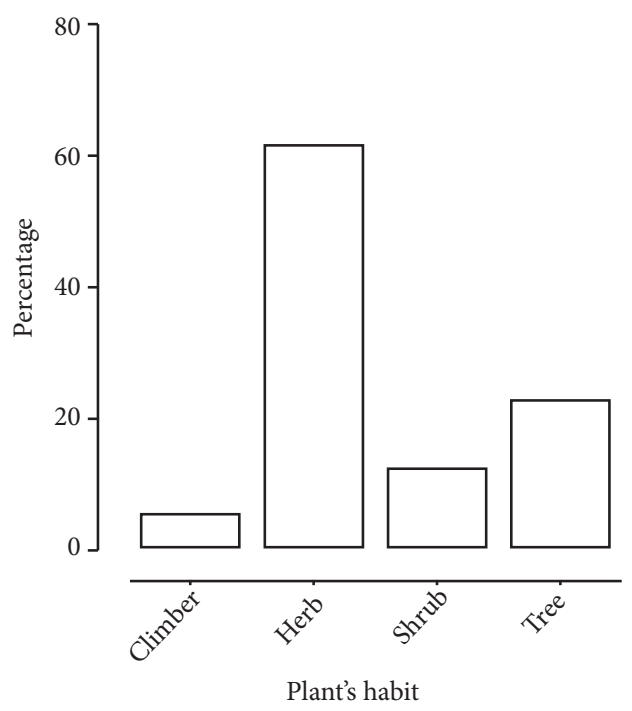

FIgURE 2: Habit-wise percentage of plants used for neurological diseases.

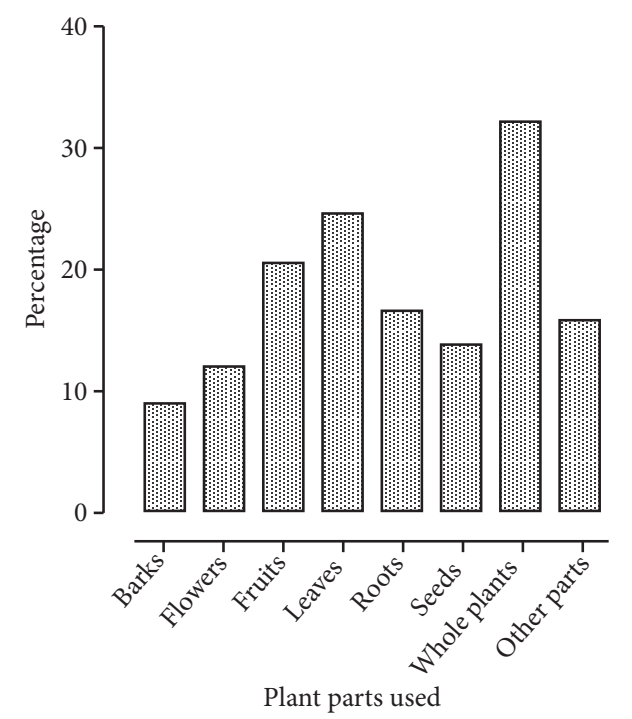

FIgURE 3: Parts-wise percentage of plants used for neurological diseases.

This district-wise plant distribution will help the researchers, who are willing to research in neuropharmacological area, to easily collect the target plants from the regions to which the plants belong. According to the plant's habit, out of total of 103 plants, $61.15 \%$ were found to be herbs, 22.33 $\%$ trees, $11.65 \%$ shrubs, and $4.85 \%$ climbers (Figure 2 ).

The habit of plants shows that herbs are most important according to neuropharmacological point of view which is another benefit for researchers working in neuropharmacological area to concentrate on herbs more while selecting neurological active plants. According to the part used of plant, whole plant, leaves, fruits, roots, seeds, flowers, and other parts (bulbs, latex, gum, tubers, and rhizome) were found to be used $32.03 \%, 24.27 \%, 20.38 \%, 16.50 \%, 13.59 \%$, $11.65 \%$, and $15.53 \%$, respectively (Figure 3 ). As some plants 


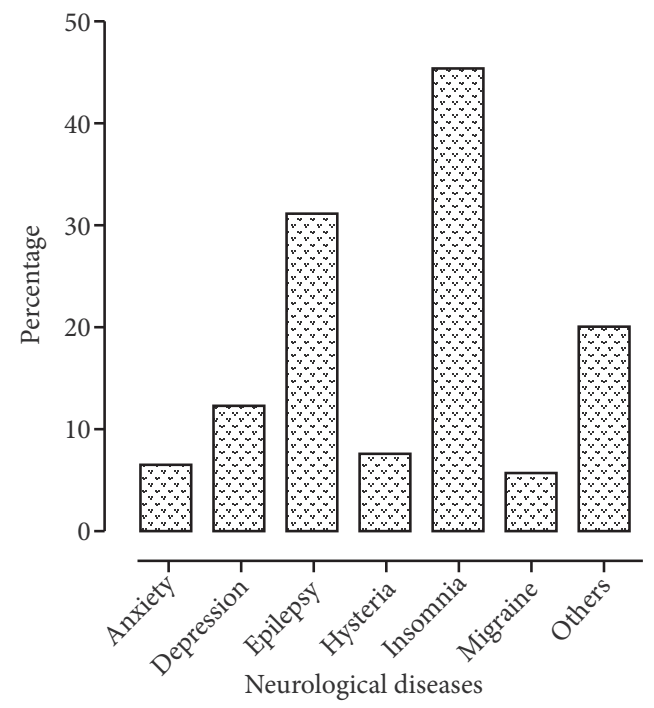

FIGURE 4: Disease-wise percentage of plants used for neurological diseases.

have more than one part to be used for various neurological diseases, so such plants were counted into percentage of all respective parts. This division of neuropharmacological plants ensures the researchers to select the most appropriate parts of plants having specific neuropharmacological activities, for their research, as used by traditional healers and folk medicine users.

According to disease's types, $45.63 \%$ were found to be of therapeutic value in insomnia, epilepsy $(31.06 \%)$, depression $(12.62 \%)$, anxiety $(6.80 \%)$, hysteria $(7.77 \%)$, and migraine $(5.88 \%)$ and $20.38 \%$ in other neurological diseases (neuralgia, mania, Parkinson, schizophrenia, and nerve pain) (Figure 4). As some plants are used for multiple neurological ailments, so such plants were counted into percentage of all respective diseases. This disease-wise plant division will help the local researchers to select their interest areas in the field of neuropharmacology, by selecting the neurological disease, for which most of the plant's percentage was found to be used by traditional healers and folk medicine users in various districts of Pakistan.

The pharmacological activities of plants are due to the presence of various phytochemicals mainly alkaloids, flavonoids, tannins, saponins, resins, glycosides, terpenoids, phenols, sterols, essential oils, vitamins, and nutrients. Some of these are effective in the treatment of neurological diseases; some are useful for cardiovascular, respiratory, and gastrointestinal diseases while others have chemotherapeutic and antibacterial effects. Some of the important phytochemicals of the plants (Table 4) including alkaloids (like nicotine and scopolamine) are reported to have anxiolytic, antidepressant, and anti-Parkinson activities [15-18], saponins (like bacosides) have been reported for anxiolytic, antiepileptic, antiamnesia, and neuroprotective and memory enhancement activities [19-22], terpenoids (like cannabigerol, tetrahydrocannabinol, and cannabidiol) are reported for their neuroprotective effects [23], flavonoids (like kaempferol, luteolin, quercetin, rutin, and hesperidin) have been reported for their anxiolytic, antidepressant, antiepileptic, anti-Alzheimer, and neuroprotective and memory enhancement activities [2430], glycosides (like hastatoside and verbenalin) are reported for sleep promoting activity [31], steroids (like sitoindosides VII-X and withaferin-A) have been reported for anxiolytic activity [32].

Bacopa monnieri plant is reported for anxiety, depressant, epilepsy, and Parkinsonism and contains alkaloids (Brahmin, nicotine, herpestine, and bacosides A \& B), saponins (hersaponin and monnierin), flavonoids (luteolin and apigenin), and sterols like b-sitosterol and stigma-sterol. These constituents are already reported for such neuropharmacological properties and so might be responsible for said activities of this plant [33-36].

Cannabis sativa $\mathrm{L}$. has been reported for the treatment of depression, anxiety, convulsion, Alzheimer, dementia, and insomnia and its constituents responsible for these properties are cannabigerol, tetrahydrocannabinol, and cannabidiol [37-41].

Verbena officinalis Linn. has been reported as anxiolytic, antidepressant, anticonvulsant, and sedative and its constituents responsible for these activities are verbenin, verbenalin, hastatoside, kaempferol, luteolin, verbascoside, aucubin, and apigenin [42-44].

Withania somnifera has been shown to have anxiolytic, antidepressant, anticonvulsant, and anti-Parkinson effects, mainly due to the presence of withanolides, sitoindosides VII-X, and withaferin-A [45-48].

These chemical constituents of plants act on the central nervous system through various mechanisms including regulation of neurotransmitters like adrenergic, cholinergic and serotonergic activity, acting through receptor like GABA and N-methyl-D-aspartate, and ion channels like sodium, potassium, and calcium ion channels. Some of the plantbased drugs and phytochemicals which either are approved or are under clinical trials for the treatment of neurological diseases, mechanism of actions, and their current status in clinical trials are given in (Table 5).

Taking into consideration this useful knowledge on the medicinal properties of plants for curing neurologic diseases, it is believed that the research in the areas of ethnomedicine and ethnopharmacology can bring auspicious results that have potential of adding importance to the very rich natural resources of Pakistan. Various phytochemicals from the above medicinal plants can be further researched under clinical trials and better drugs for treatment of neurological diseases can be obtained with outstanding results and lesser side effects. This study will help all the researchers, especially from Asian countries including Pakistan, China, Iran, India, Sri Lanka, and Bangladesh, working on plants based medicine for neurological diseases.

\section{Conclusion}

The mental illnesses are one of the major problems of the world mainly in communities presenting with poor socioeconomic conditions. In Pakistan and other countries 


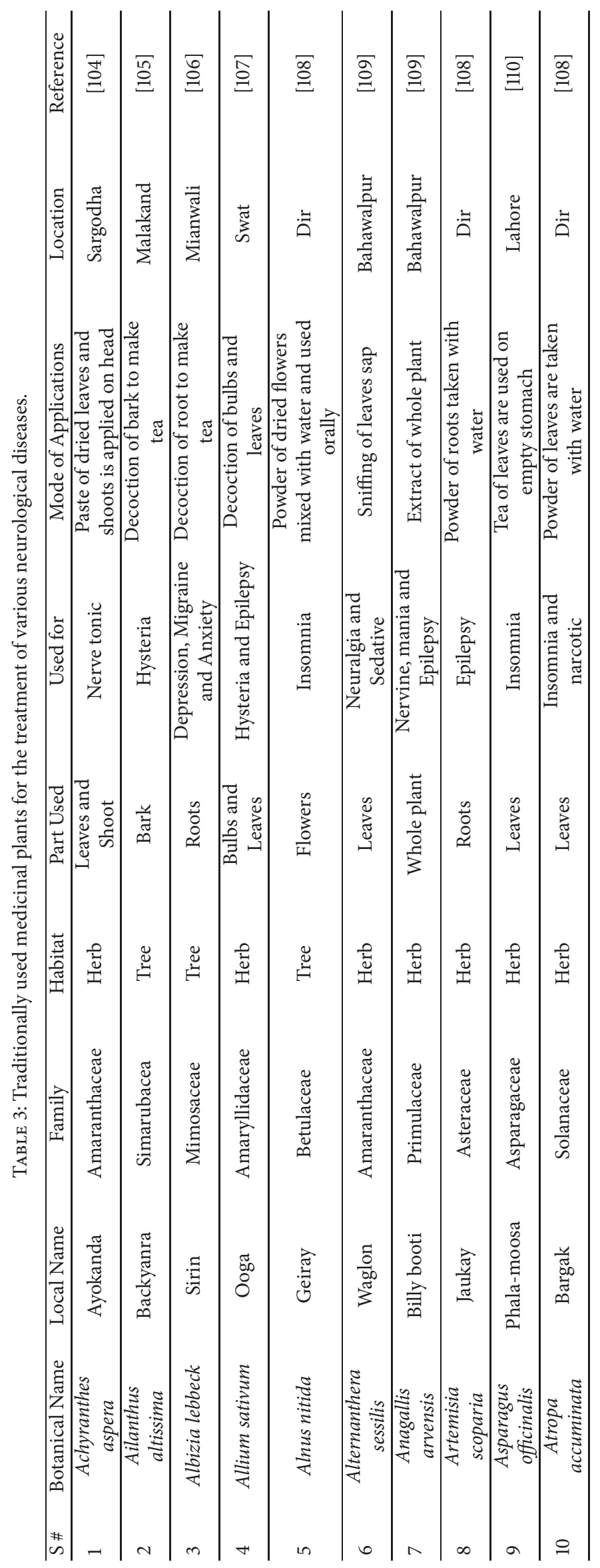




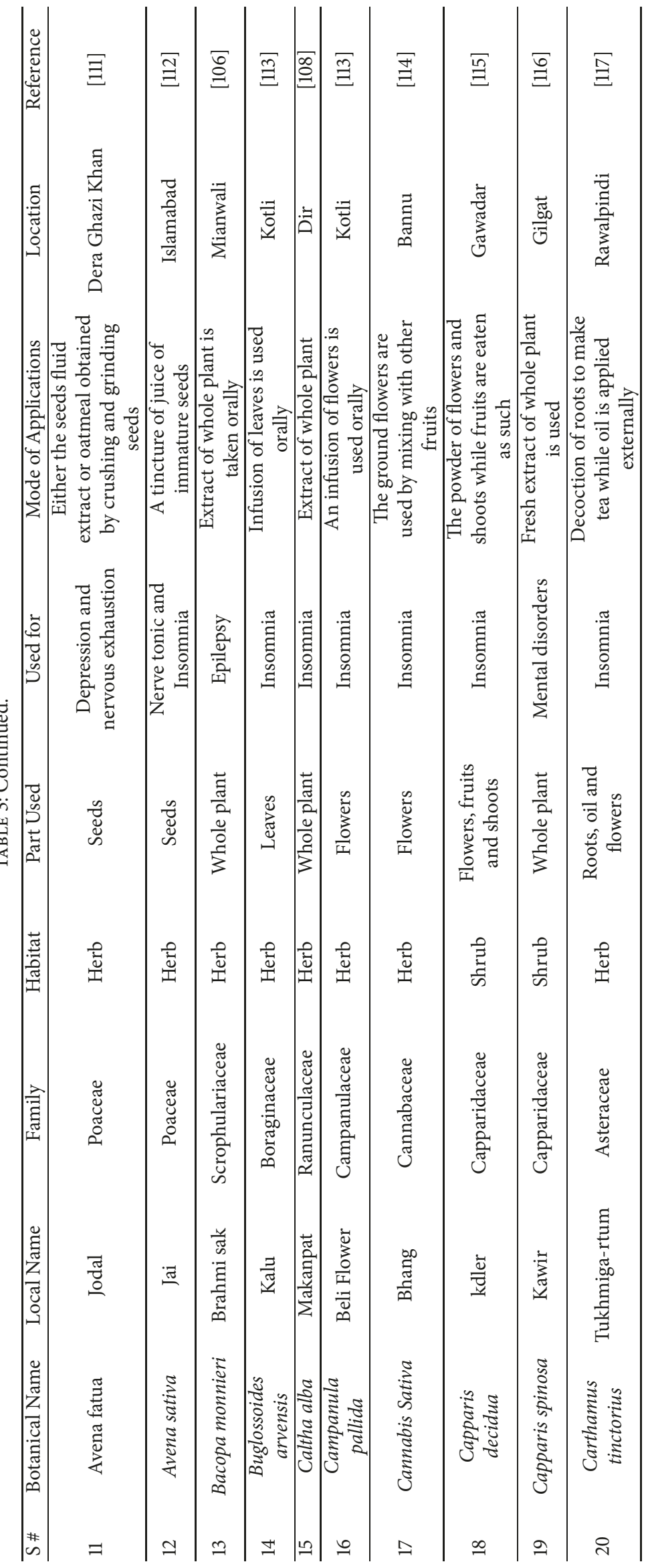




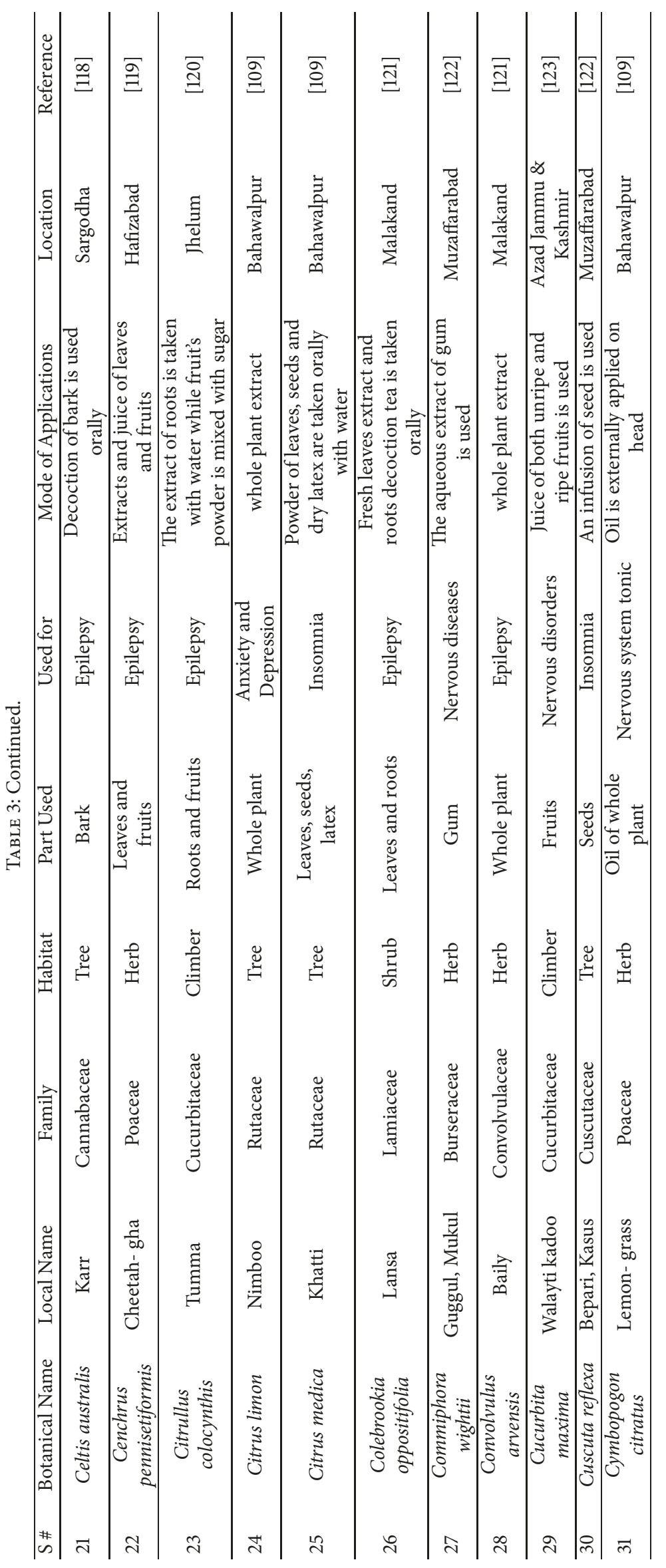




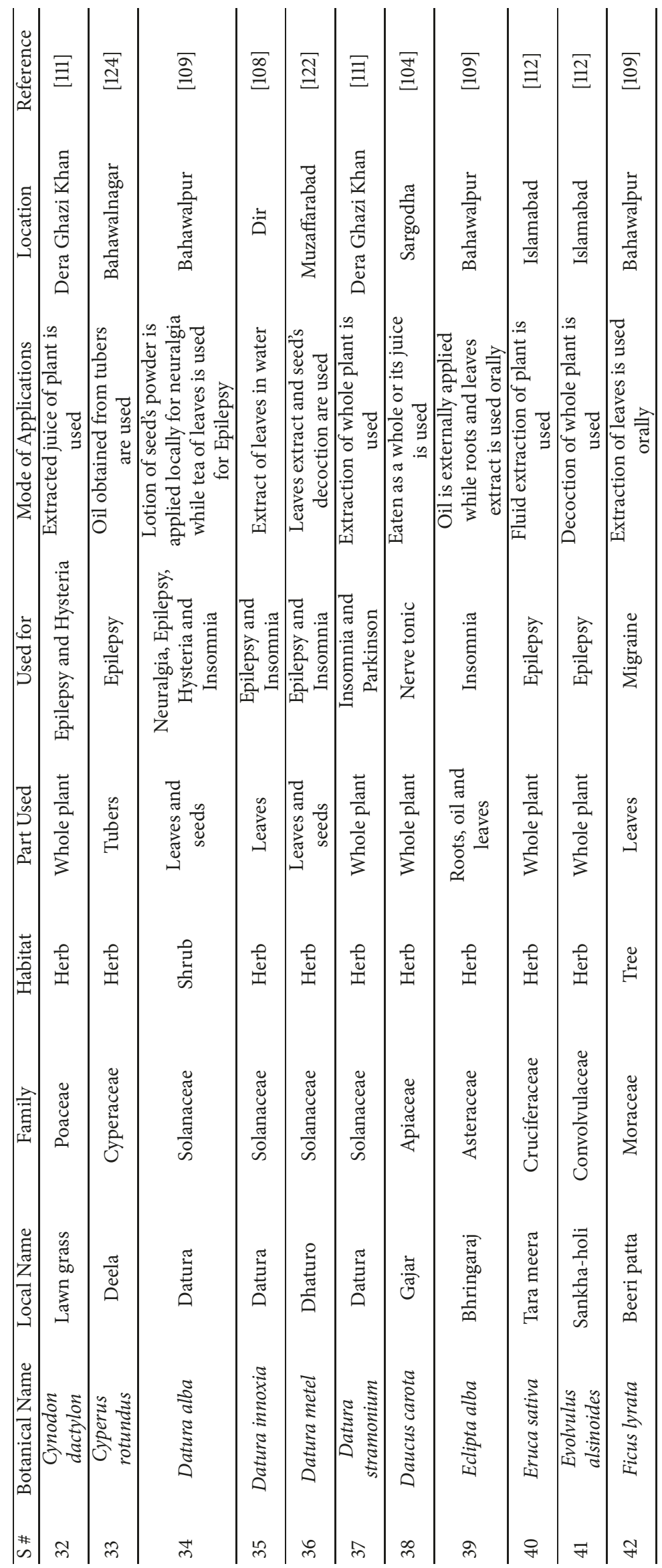




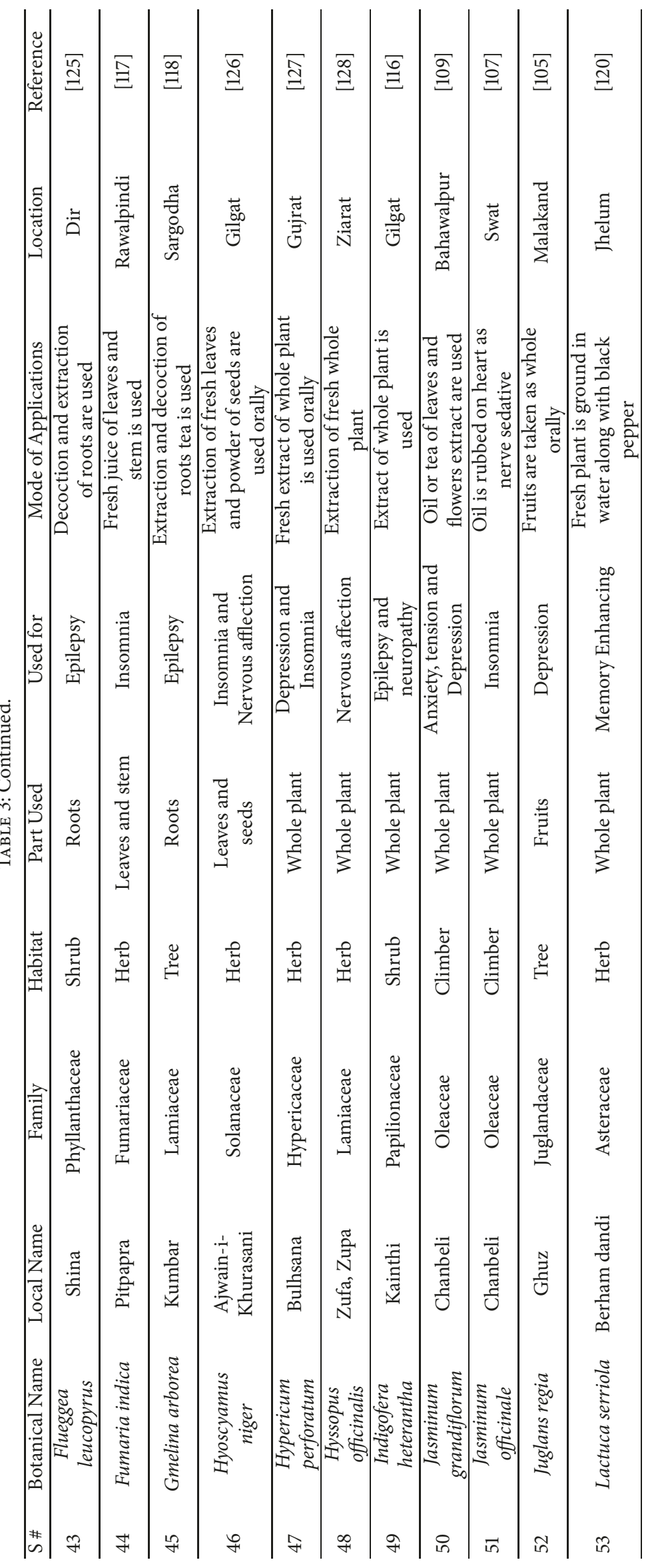




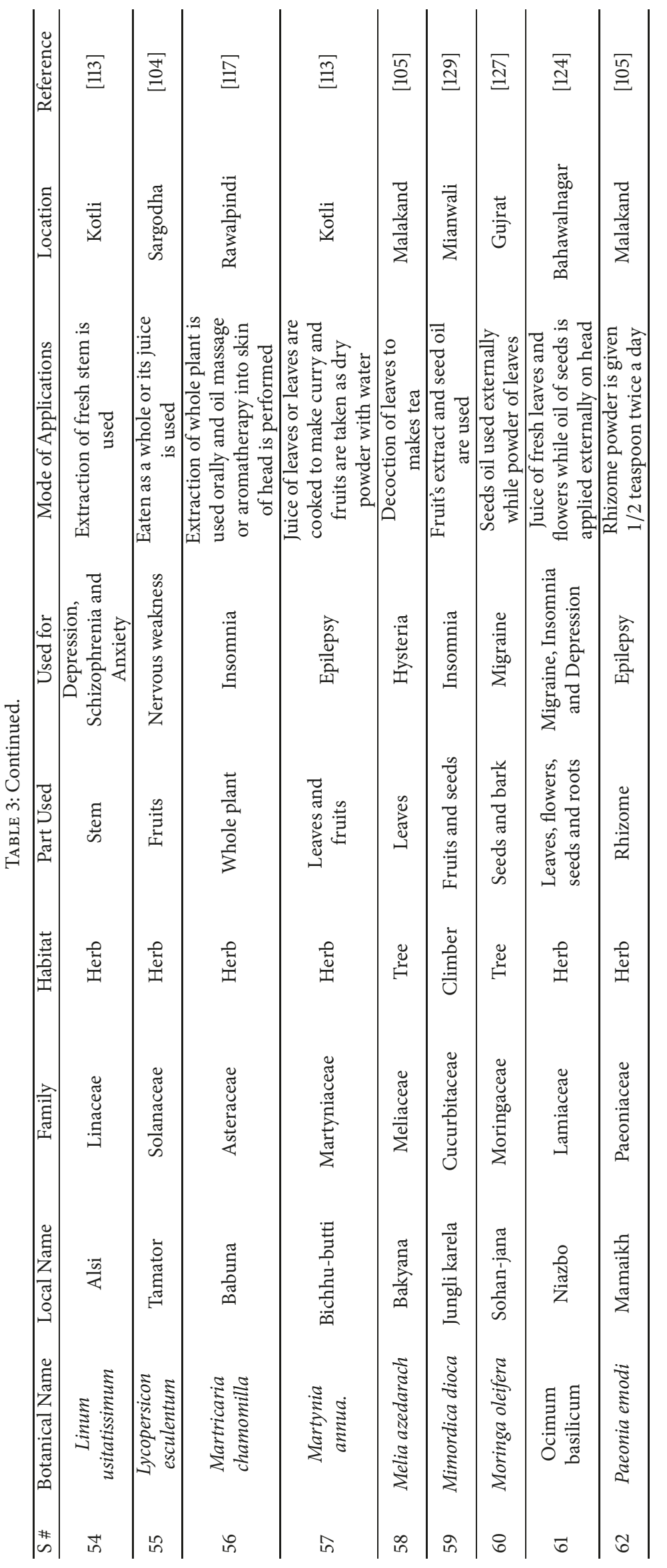




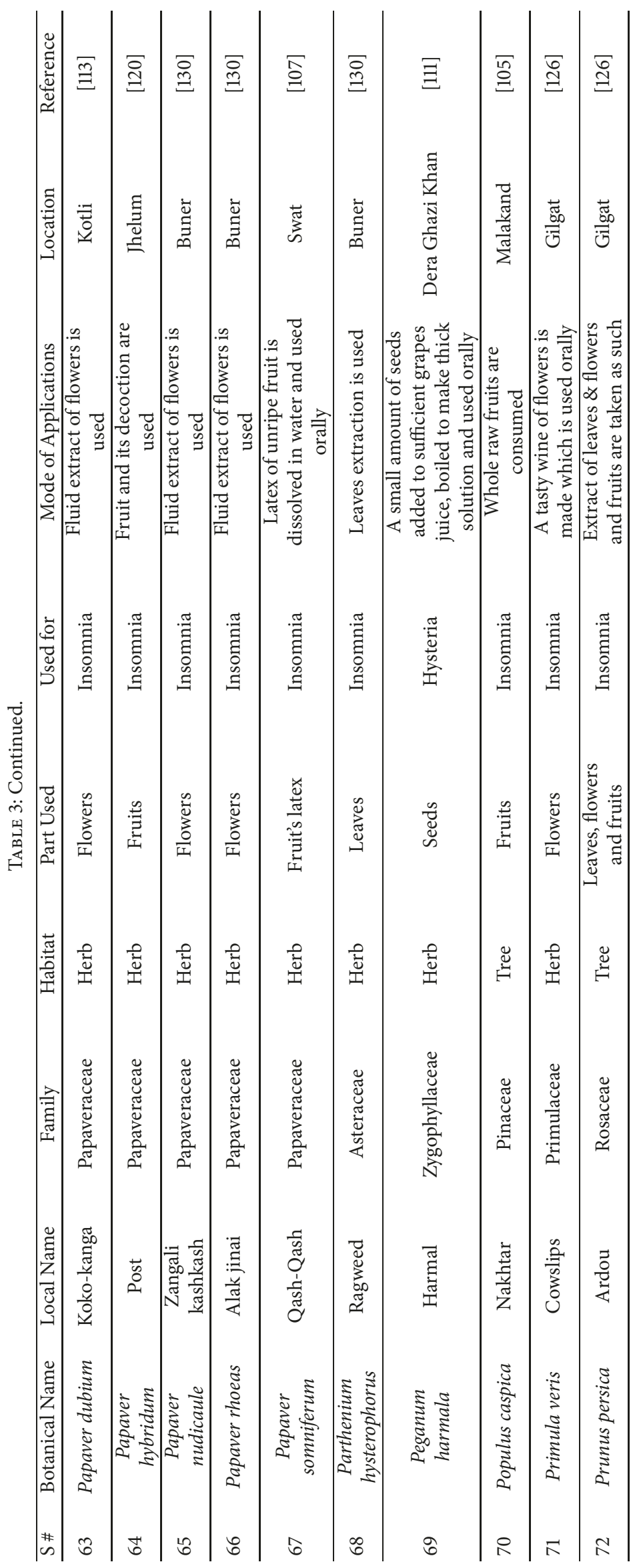




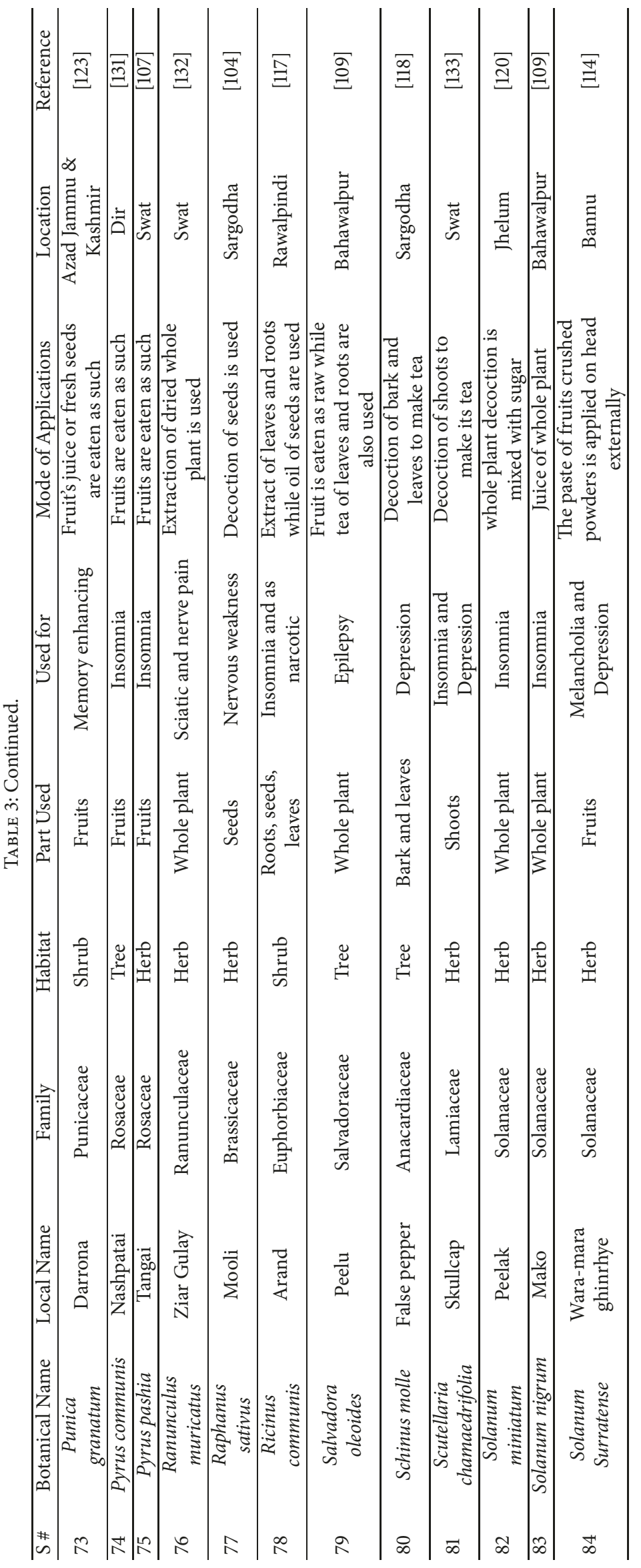




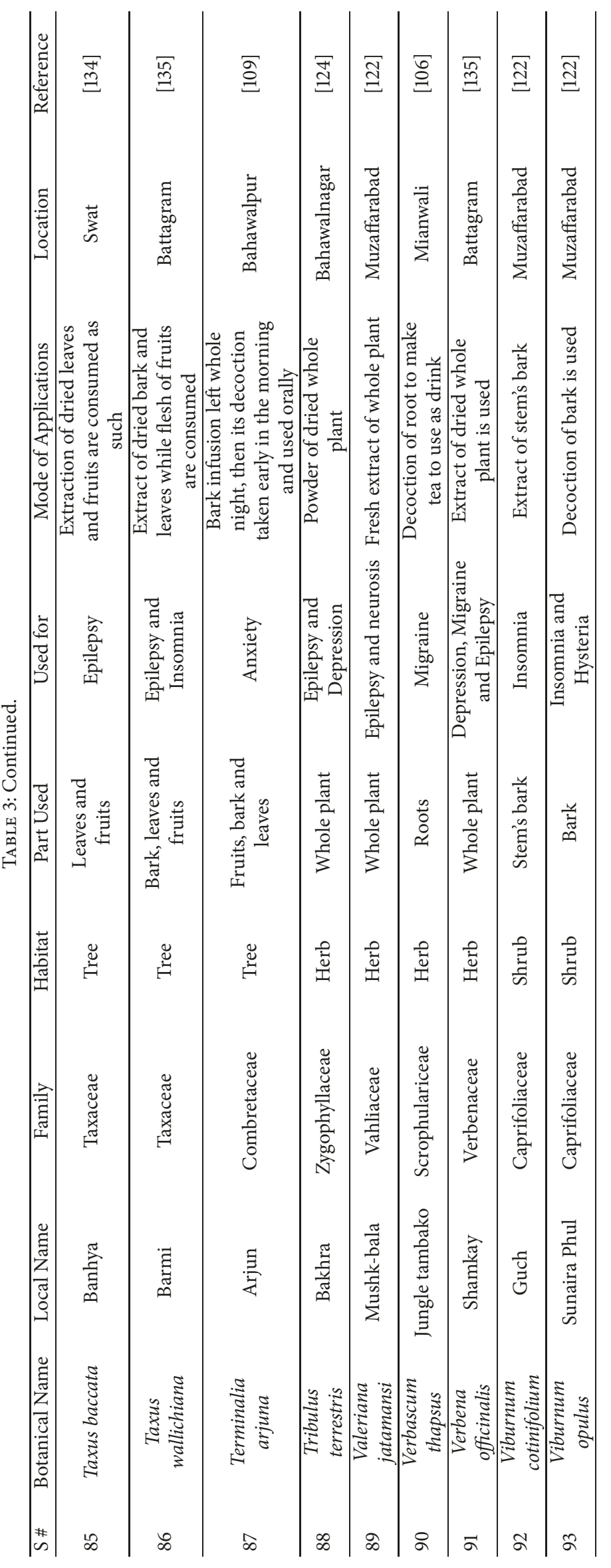




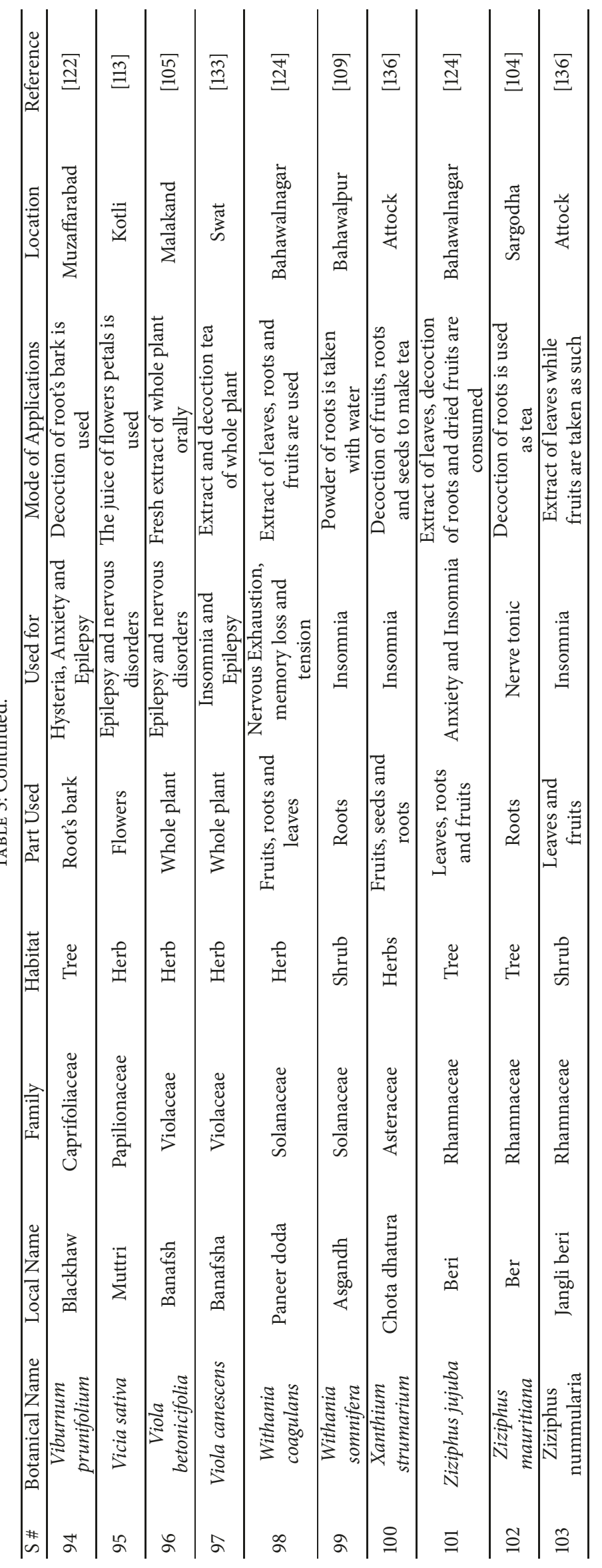




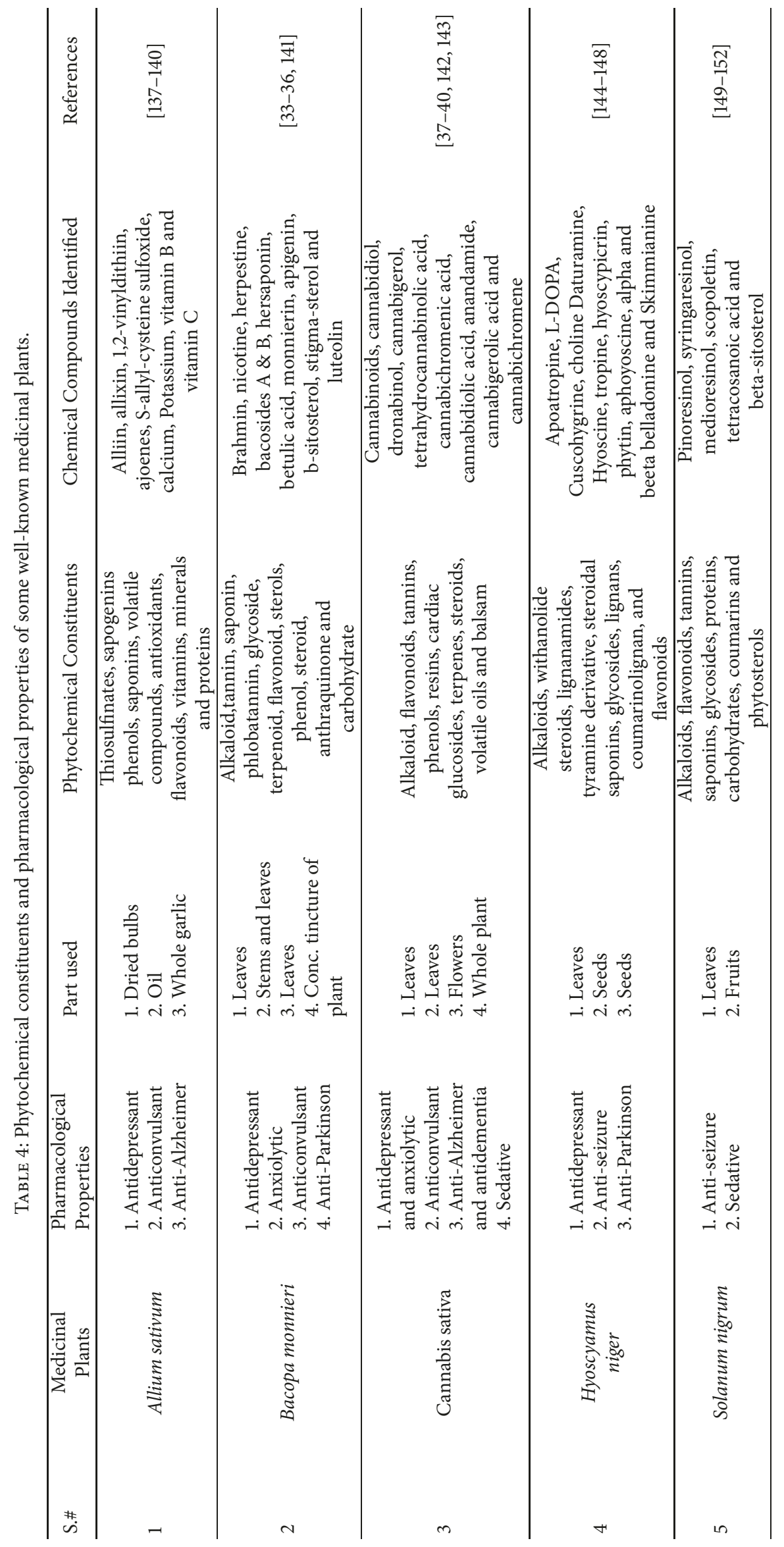




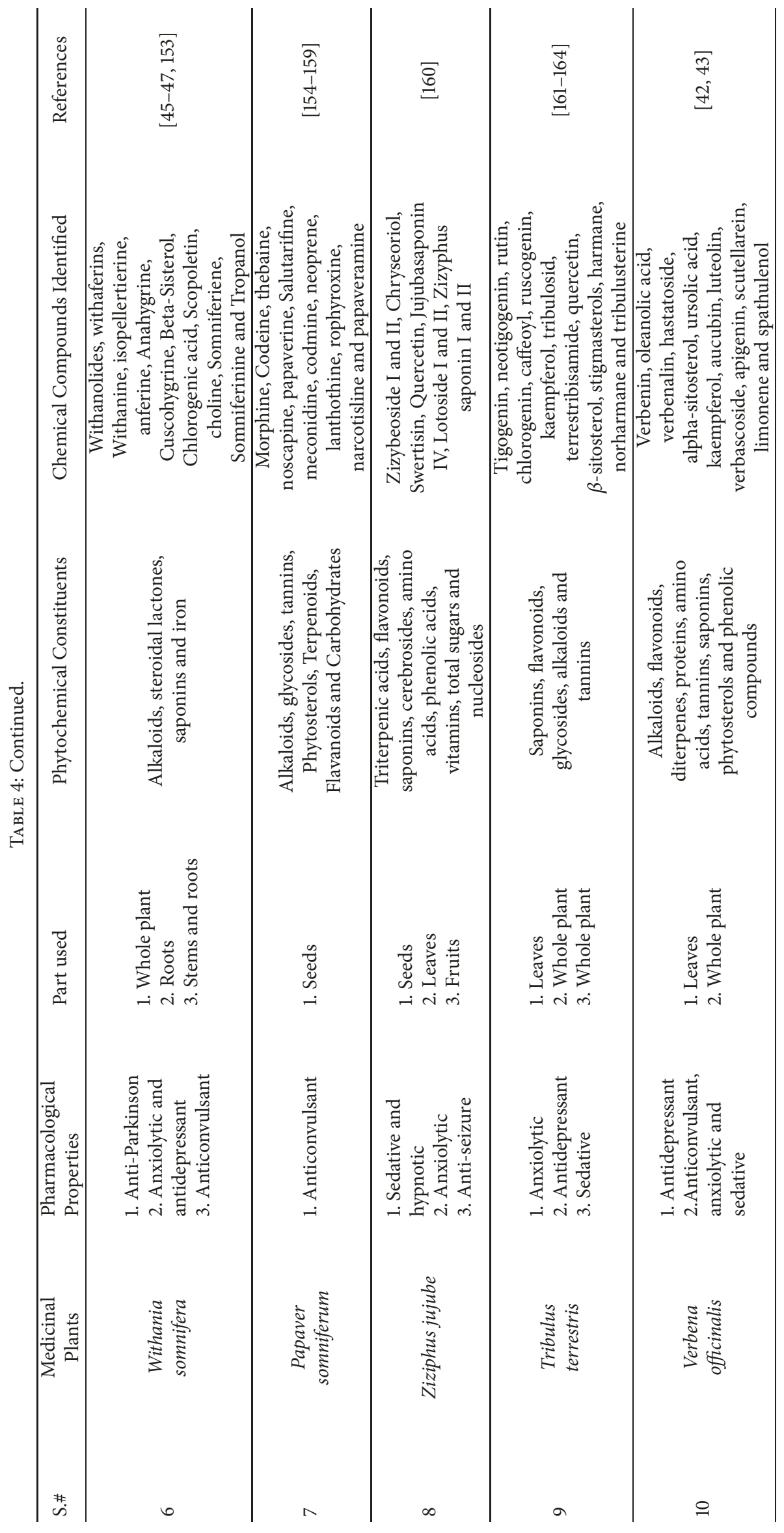




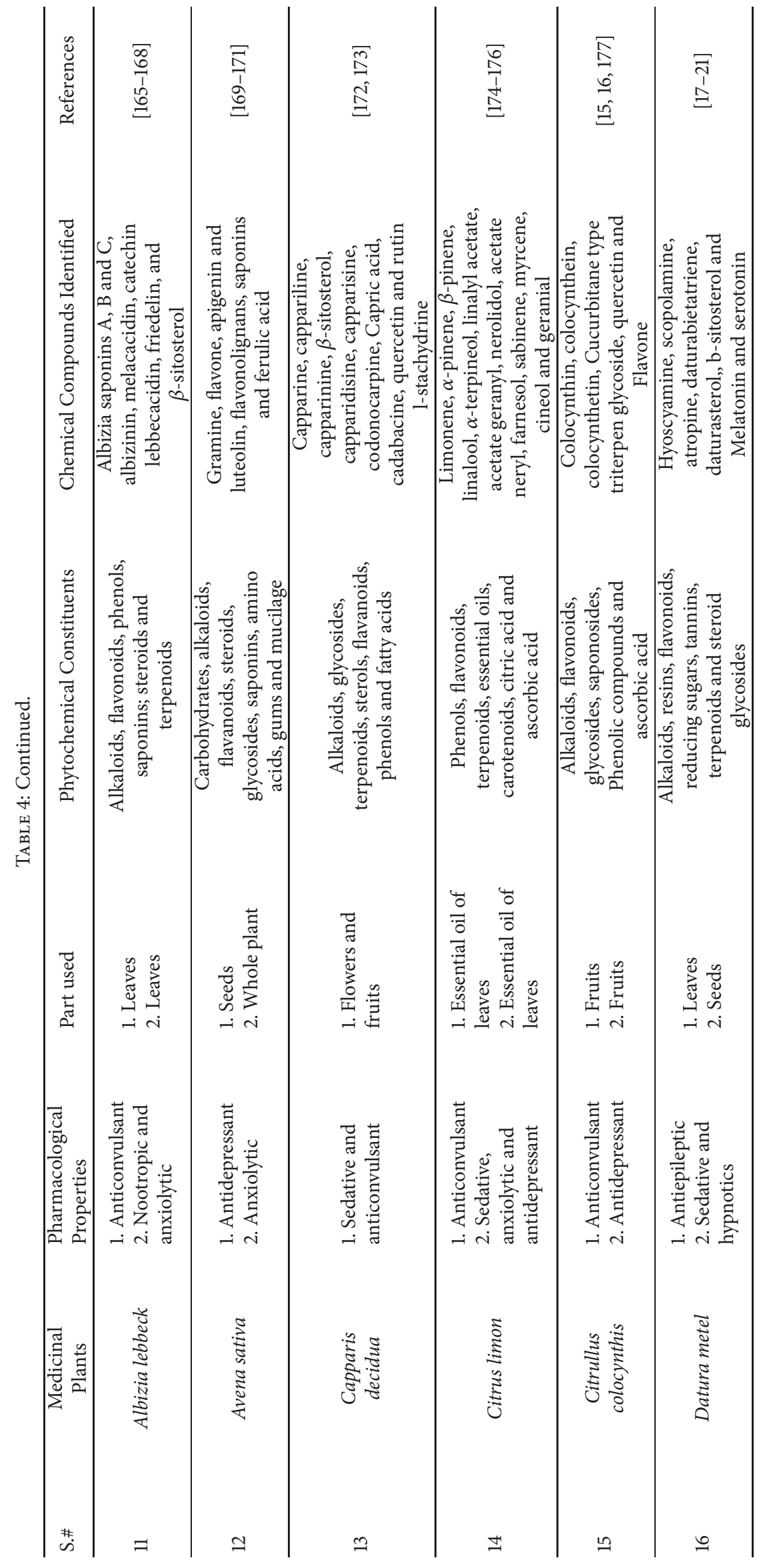




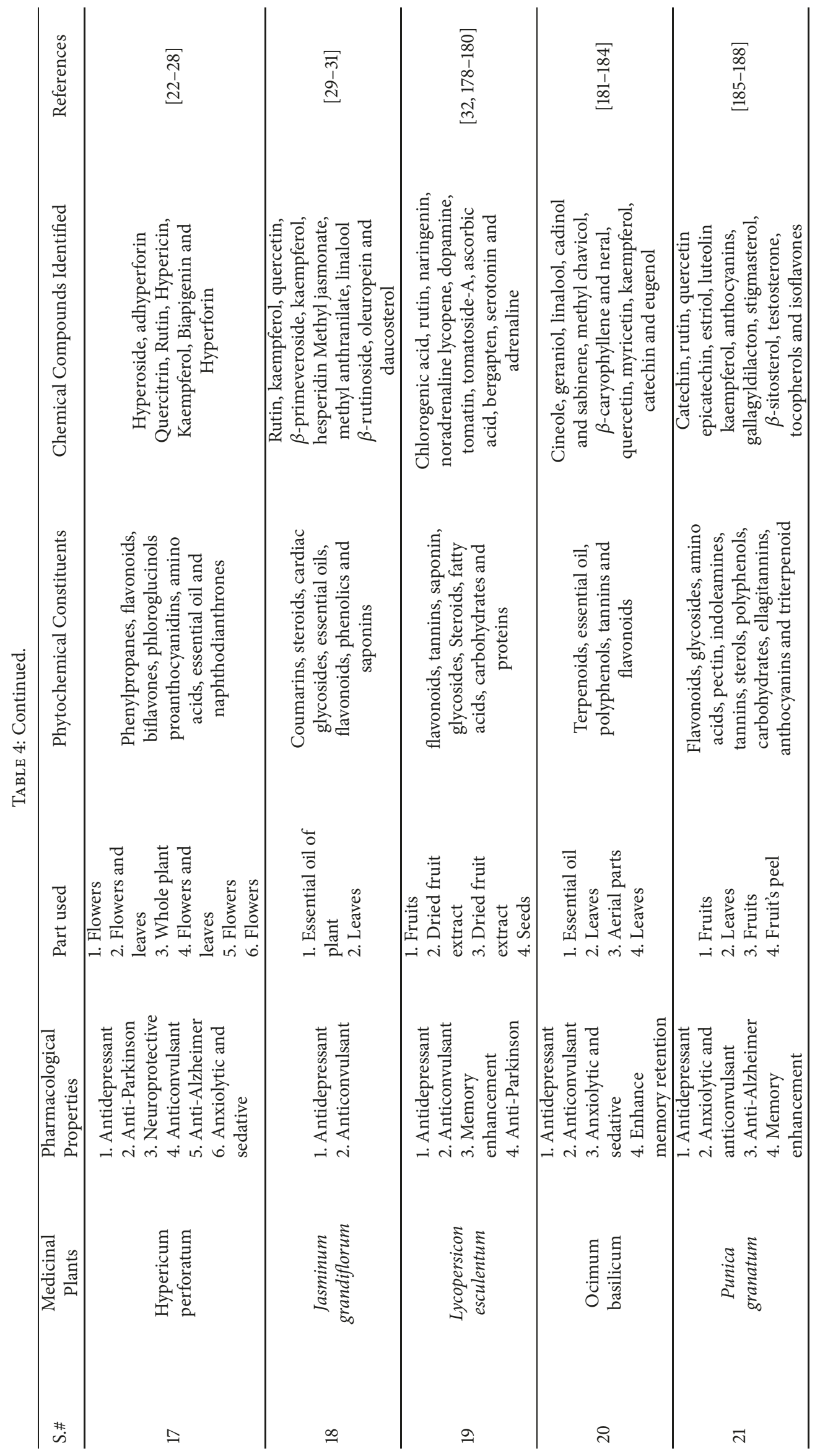




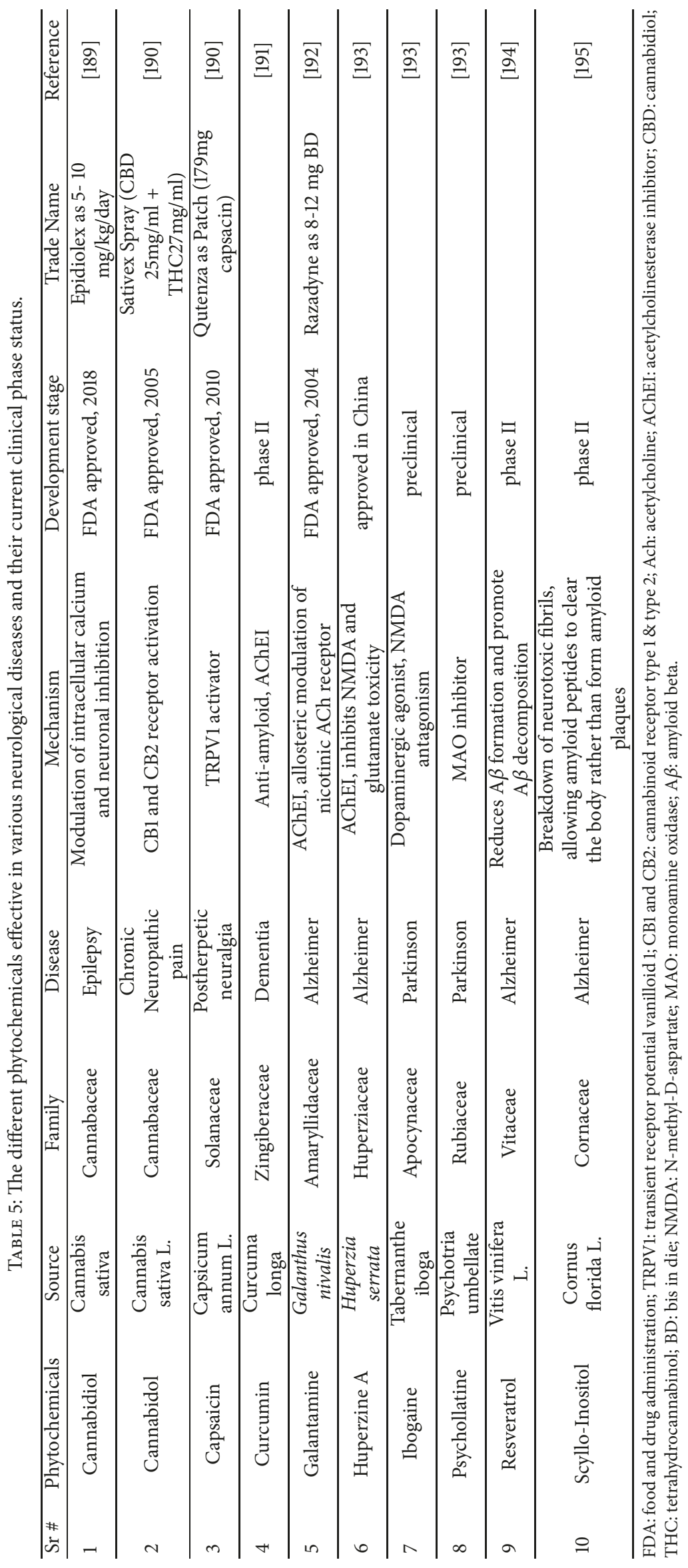


of this region, there is no accurate and up to date record of the neurological ailments. In order to find any treatment for these diseases, first realistic survey would be required to find out the exact percentage of various neurological diseases. Being an alarming psychiatric problem, Alzheimer opens a new area of research, affecting an enormous part of world population, but it is still untreatable. A lot of attempts have been conducted but still there is no such drug that can either slow or stop the process of Alzheimer disease. Allopathic medicines are available for psychological diseases including anxiety, depression, epilepsy, Parkison, and Alzheimer, but these are either not so effective or costly or have serious associated adverse effects. The world is full of natural medicinal resources, of which the main source is plant. We should invest money and go for systemic scientific investigations to perceive such drug candidates' form these plants, which are most efficacious, have minor side effects, and are cost friendly. For this purpose, this study is a gift for researchers who have interest to design and perform research based activities in the field of neuropharmacology by evaluating the unexplored medicinal plants mentioned here for their folkloric uses, determining its mechanistic pathways and identifying chemical constituents responsible for therapeutic effects.

\section{Data Availability}

No personal data was collected from the interviewees and therefore no such data is kept or shared in any form.

\section{Consent}

Prior informed consent was obtained from all participants before conducting interviews. This manuscript does not contain any individual person's data and further consent for publication is not required.

\section{Conflicts of Interest}

The authors declare that they have no conflicts of interest.

\section{Authors' Contributions}

Abdul Waheed Khan, Arif-ullah Khan, and Syed Muhammad Mukarram Shah designed the study, performed field work, and researched various medicinal plants articles on scientific search engines. Aziz Ullah, Muhammad Faheem, and Muhammad Saleem analyzed the data and drafted the manuscript. All authors read and approved the final manuscript.

\section{Acknowledgments}

The authors heartily thank all the contributors for taking part and sharing their valuable knowledge with us. They humbly acknowledge Mr. Muhammad Adnan, Mr. Mubashir Shahid, Mr. Rooh Ullah, Mr. Imran ul Haq, Mr. Najeeb Shah, Mr Rizwan Ullah, Ms Qurat ul Ain, Ms. Fizza Bukhari, and Ms Rubia Anwar for their continuous support in the dissemination and collection of the questionnaires in various districts of Pakistan.

\section{References}

[1] G. Hussain, H. Anwar, A. Shahzad et al., "Neurological disorder burden in faisalabad, punjab-pakistan: data from the major tertiary carecenters of the city," Pakistan Journal of Neurological Sciences (PJNS), vol. 12, no. 3, pp. 3-10, 2017.

[2] S. Guo, "Using zebrafish to assess the impact of drugs on neural development and function," Expert Opinion on Drug Discovery, vol. 4, no. 7, pp. 715-726, 2009.

[3] A. A. Gadit, "State of mental health in Pakistan.," Journal of the Pakistan Medical Association, vol. 51, no. 7, pp. 238-239, 2001.

[4] S. Awan, S. Shafqat, A. K. Kamal et al., "Pattern of neurological diseases in adult outpatient neurology clinics in tertiary care hospital," BMC Research Notes, vol. 10, no. 1, p. 545, 2017.

[5] W. H. Organization, Neurological Disorders: Public Health Challenges, World Health Organization, 2006.

[6] A. Sofowora, E. Ogunbodede, and A. Onayade, "The role and place of medicinal plants in the strategies for disease prevention," The African Journal of Traditional, Complementary, and Alternative Medicines, vol. 10, no. 5, pp. 210-229, 2013.

[7] N. H. Rakotoarivelo, F. Rakotoarivony, A. V. Ramarosandratana et al., "Medicinal plants used to treat the most frequent diseases encountered in Ambalabe rural community, Eastern Madagascar," Journal of Ethnobiology and Ethnomedicine, vol. 11, no. 1, p. 68, 2015.

[8] J. S. C. Júnior, A. B. Ferraz, T. O. Sousa et al., "Investigation of biological activities of dichloromethane and ethyl acetate fractions of platonia insignis mart. seed," Basic \& Clinical Pharmacology \& Toxicology, vol. 112, no. 1, pp. 34-41, 2013.

[9] M. Govindappa, "A review on role of plant (s) extracts and its phytochemicals for the management of diabetes," Journal of Diabetes \& Metabolism, vol. 6, no. 7, Article ID 1000565, 2015.

[10] Y. Gupta, "Indian traditional medicine in neurological disorders," Planta Medica, vol. 78, no. 05, p. OP19, 2012.

[11] H. Kanwal and B. A. Sherazi, "Herbal medicine: trend of practice, perspective, and limitations in pakistan," Asian Pacific Journal of Health Sciences, vol. 4, no. 4, pp. 6-8, 2017.

[12] R. A. Qureshi, M. A. Ghufran, S. Gilani, Z. Yousaf, G. A. Miana, and A. Batool, "Indigenous medicinal plants used by local women in southern himalayan regions of pakistan," Pakistan Journal of Botany, vol. 41, no. 1, pp. 19-25, 2009.

[13] A. Mahmood, A. Mahmood, H. Shaheen, R. A. Qureshi, Y. Sangi, and S. A. Gilani, "Ethno medicinal survey of plants from district bhimber azad jammu and kashmir, pakistan," Journal of Medicinal Plants Research, vol. 5, no. 11, pp. 2348-2360, 2011.

[14] H. Bhatia, Y. P. Sharma, R. K. Manhas, and K. Kumar, "Ethnomedicinal plants used by the villagers of district Udhampur, J\&K, India," Journal of Ethnopharmacology, vol. 151, no. 2, pp. 1005-1018, 2014.

[15] B. Pravin, D. Tushar, P. Vijay, and K. Kishanchnad, "Review on citrullus colocynthis," International Journal of Research in Pharmaceutical Sciences, vol. 3, no. 1, pp. 46-53, 2013.

[16] S. Mehrzadi, A. Shojaii, S. A. Pur, and M. Motevalian, "Anticonvulsant activity of hydroalcoholic extract of citrullus colocynthis fruit: involvement of benzodiazepine and opioid receptors," Evidence-Based Complementary and Alternative Medicine, vol. 21, no. 4, pp. NP31-NP35, 2016. 
[17] M. Ali and M. Shuaib, "Characterization of the chemical constituents of datura mete/linn," Indian Journal of Pharmaceutical Sciences, vol. 58, no. 6, pp. 243-245, 1996.

[18] S. J. Murch, A. R. Alan, J. Cao, and P. K. Saxena, "Melatonin and serotonin in flowers and fruits of datura metel L," Journal of Pineal Research, vol. 47, no. 3, pp. 277-283, 2009.

[19] S. Babalola, M. Suleiman, A. Hassan, and D. Adawa, "Evaluation of datura metel L seed extract as a sedative/hypnotic: a priliminary study," Journal of Veterinary Advances, vol. 5, no. 4, p. 857, 2015.

[20] A. Tijani, U. Eyineyi, J. Ibrahim, and S. Okhale, "Neurotoxicological impacts of datura metel linn. (family: solanaceae) leaves extract in mice," The Journal of Neurobehavioral Sciences, vol. 2, no. 3, pp. 97-101, 2015.

[21] C. Bhawana, S. Sushil, and S. Amit, "Evaluation of antiepileptic activity of datura metel leaf extract in experimental animal," International Journal of Research in Pharmacy and Chemistry, vol. 6, no. 3, 2016.

[22] A. Nahrstedt and V. Butterweck, "Biologically active and other chemical constituents of the herb of hypericum perforation L," Pharmacopsychiatry, vol. 30, no. 2, pp. 129-134, 1997.

[23] H. Hosseinzadeh, G.-R. Karimi, and M. Rakhshanizadeh, "Anticonvulsant effect of hypericum perforatum: role of nitric oxide," Journal of Ethnopharmacology, vol. 98, no. 1-2, pp. 207-208, 2005.

[24] A. Rezaie, K. R. Dorostkar, M. Pashazadeh, and S. M. Nejad, "Study of sedative and anxiolytic effects of herbal extract hypericum perforatum in comparison with diazepam in rats," International Journal of Infectious Diseases, vol. 12, p. e171, 2008.

[25] J. Tian, F. Zhang, J. Cheng, S. Guo, P. Liu, and H. Wang, "Antidepressant-like activity of adhyperforin, a novel constituent of hypericum perforatum L," Scientific Reports, vol. 4, p. 5632, 2014.

[26] D. D. Vecchia, M. G. Schamne, M. M. Ferro et al., "Effects of hypericum perforatum on turning behavior in an animal model of parkinson's disease," Brazilian Journal of Pharmaceutical Sciences, vol. 51, no. 1, pp. 111-115, 2015.

[27] A. I. Oliveira, C. Pinho, B. Sarmento, and A. C. P. Dias, "Neuroprotective activity of hypericum perforatum and its major components," Frontiers in Plant Science, vol. 7, p. 1004, 2016.

[28] K. Zerrouki, N. Djebli, E. E. Ozkan, N. Ozsoy, O. Gul, and A. Mat, "Hypericum perforatum improve memory and learning in alzheimer's model: (experimental study in mice)," International Journal of Pharmacy and Pharmaceutical Sciences, vol. 8, no. 8, pp. 49-57, 2016.

[29] P. Kunhachan, C. Banchonglikitkul, T. Kajsongkram, A. Khayungarnnawee, and W. Leelamanit, "Chemical composition, toxicity and vasodilatation effect of the flowers extract of jasminum sambac (L.) ait. "g. duke of tuscany"," Evidence-Based Complementary and Alternative Medicine, vol. 2012, Article ID 471312, 7 pages, 2012.

[30] R. K. Gupta and P. S. Reddy, "Antinociceptive and anticonvulsant activities of hydroalcoholic extract of Jasminum grandiflorum (jasmine) leaves in experimental animals," Pharmacognosy Research, vol. 5, no. 4, pp. 286-290, 2013.

[31] S. Umukoro, A. Adebesin, G. Agu, O. Omorogbe, and S. B. Asehinde, "Antidepressant-like activity of methyl jasmonate involves modulation of monoaminergic pathways in mice," Advances in Medical Sciences, vol. 63, no. 1, pp. 36-42, 2018.
[32] P. Milind and M. Suman, "Eat tomato a day to keep depression at bay," Asian Journal of Biological Sciences, vol. 4, no. 2, pp. 258262, 2009.

[33] S. K. Bhattacharya and S. Ghosal, "Anxiolytic activity of a standardized extract of Bacopa monniera: an experimental study," Phytomedicine, vol. 5, no. 2, pp. 77-82, 1998.

[34] D. Kaushik, A. Tripathi, R. Tripathi, M. Ganachari, and S. A. Khan, "Anticonvulsant activity of bacopa monniera in rodents," Brazilian Journal of Pharmaceutical Sciences, vol. 45, no. 4, pp. 643-649, 2009.

[35] P. Jadiya, A. Khan, S. R. Sammi, S. Kaur, S. S. Mir, and A. Nazir, "Anti-parkinsonian effects of bacopa monnieri: insights from transgenic and pharmacological caenorhabditis elegans models of parkinson's disease," Biochemical and Biophysical Research Communications, vol. 413, no. 4, pp. 605-610, 2011.

[36] M. A. Mannan, A. B. Abir, and M. R. Rahman, "Antidepressantlike effects of methanolic extract of bacopa monniera in mice," BMC Complementary and Alternative Medicine, vol. 15, no. 1, p. 337, 2015.

[37] E. A. Carlini and J. M. Cunha, "Hypnotic and antiepileptic effects of cannabidiol," The Journal of Clinical Pharmacology, vol. 21, 1, no. 8-9, pp. 417S-427S, 1981.

[38] J. T. Pickens, "Sedative activity of cannabis in relation to its $\Delta$ '-trans-tetrahydrocannabinol and cannabidiol content," British Journal of Pharmacology, vol. 72, no. 4, pp. 649-656, 1981.

[39] L. Volicer, M. Stelly, J. Morris, J. McLaughlin, and B. J. Volicer, "Effects of dronabinol on anorexia and disturbed behavior in patients with alzheimer's disease," International Journal of Geriatric Psychiatry, vol. 12, no. 9, pp. 913-919, 1997.

[40] A. R. M. de Schier, N. P. O. de Ribeiro, D. S. Coutinho et al., "Antidepressant-like and anxiolytic-like effects of cannabidiol: a chemical compound of Cannabis sativa," CNS \& Neurological Disorders-Drug Targets (Formerly Current Drug Targets-CNS \& Neurological Disorders), vol. 13, no. 6, pp. 953-960, 2014.

[41] S. Valdeolivas, C. Navarrete, I. Cantarero, M. L. Bellido, E. Muñoz, and O. Sagredo, "Neuroprotective properties of cannabigerol in huntington's disease: studies in R6/2 mice and 3-nitropropionate-lesioned mice," Neurotherapeutics, vol. 12, no. 1, pp. 185-199, 2015.

[42] T. Jawaid, S. A. Imam, and M. Kamal, "Antidepressant activity of methanolic extract of Verbena Officinalis Linn. plant in mice," Asian Journal of Pharmaceutical and Clinical Research, vol. 8, no. 4, pp. 308-310, 2015.

[43] A. W. Khan, A.-U. Khan, and T. Ahmed, "Anticonvulsant, anxiolytic, and sedative activities of Verbena officinalis," Frontiers in Pharmacology, vol. 7, 2016.

[44] Y. Makino, S. Kondo, Y. Nishimura, Y. Tsukamoto, Z.L. Huang, and Y. Urade, "Hastatoside and verbenalin are sleep-promoting components in verbena officinalis," Sleep and Biological Rhythms, vol. 7, no. 3, pp. 211-217, 2009.

[45] S. K. Bhattacharya, A. Bhattacharya, K. Sairam, and S. Ghosal, "Anxiolytic-antidepressant activity of Withania somnifera glycowithanolides: an experimental study," Phytomedicine, vol. 7, no. 6, pp. 463-469, 2000.

[46] M. Ahmad, S. Saleem, A. S. Ahmad et al., "Neuroprotective effects of Withania somnifera on 6-hydroxydopamine induced Parkinsonism in rats," Human \& Experimental Toxicology, vol. 24, no. 3, pp. 137-147, 2005.

[47] S. K. Raju, P. L. Basavanna, H. N. Nagesh, and A. D. Shanbhag, "A study on the anticonvulsant activity of Withania somnifera (Dunal) in albino rats," National Journal of Physiology, Pharmacy and Pharmacology, vol. 7, no. 1, pp. 17-21, 2017. 
[48] S. K. Bhattacharya, R. K. Goel, R. Kaur, and S. Ghosal, "Anti-stress activity of sitoindosides VII and VIII, new acylsterylglucosides from withania somnifera," Phytotherapy Research, vol. 1, no. 1, pp. 32-37, 1987.

[49] R. C. Burch, S. Loder, E. Loder, and T. A. Smitherman, "The prevalence and burden of migraine and severe headache in the united states: updated statistics from government health surveillance studies," Headache: The Journal of Head and Face Pain, vol. 55, no. 1, pp. 21-34, 2015.

[50] D. Kadojić, M. Dikanović, M. Bitunjac, V. Vuletić, L. Čengić, and B. Bijelić, "Epidemiology of Stroke," Periodicum Biologorum, vol. 114, no. 3, pp. 253-257, 2012.

[51] G. Hussain, A. Rasul, H. Anwar et al., "Epidemiological data of neurological disorders in pakistan and neighboring countries: a review," Pakistan Journal of Neurological Sciences (PJNS), vol. 12, no. 4, pp. 52-70, 2017.

[52] W. H. Organization, Depression and Other Common Mental Disorders: Global Health Estimates, 2017.

[53] D. M. Radhakrishnan and V. Goyal, "Parkinson's disease: a review," Neurology India, vol. 66, no. 7, p. 26, 2018.

[54] C. P. Ferri, M. Prince, C. Brayne et al., "Global prevalence of dementia: a Delphi consensus study," The Lancet, vol. 366, no. 9503, pp. 2112-2117, 2005.

[55] K. P. Peng and S. J. Wang, "Epidemiology of headache disorders in the a sia-p acific region," Headache: The Journal of Head and Face Pain, vol. 54, no. 4, pp. 610-618, 2014.

[56] N. Venketasubramanian, B. W. Yoon, J. Pandian, and J. C. Navarro, "Stroke epidemiology in south, east, and south-east asia: A review," Journal of Stroke, vol. 19, no. 3, pp. 286-294, 2017.

[57] S. Churl, "The worldwide prevalence of epilepsy: a systematic review and meta-analysis," Epilepsy Currents, vol. 13, p. 322, 2013.

[58] O. Remes, C. Brayne, R. van der Linde, and L. Lafortune, "A systematic review of reviews on the prevalence of anxiety disorders in adult populations," Brain and Behavior, vol. 6, no. 7, p. e00497, 2016.

[59] T. Pringsheim, N. Jette, A. Frolkis, and T. D. L. Steeves, “The prevalence of parkinson's disease: a systematic review and metaanalysis," Movement Disorders, vol. 29, no. 13, pp. 1583-1590, 2014.

[60] Y. W. Woldeamanuel, A. P. Andreou, and R. P. Cowan, "Prevalence of migraine headache and its weight on neurological burden in Africa: A 43-year systematic review and meta-analysis of community-based studies," Journal of the Neurological Sciences, vol. 342, no. 1-2, pp. 1-15, 2014.

[61] D. Adeloye, "An estimate of the incidence and prevalence of stroke in Africa: A systematic review and meta-analysis," PLoS ONE, vol. 9, no. 6, p. e100724, 2014.

[62] Diseases, O.M.d.l.S.P.f.N et al., Atlas: Epilepsy Care in The World, World Health Organization, 2005.

[63] D. G. Massi, "Epidemiology of Parkinsons disease in Africa: Challenges and opportunities. Parkinsonism Related Disorders," in Epidemiology of Parkinson's disease in Africa: Challenges and opportunities. Parkinsonism Related Disorders, pp. 46-e10, p. e10, 46, 2018.

[64] R. B. Lipton and M. E. Bigal, "Migraine: epidemiology, impact, and risk factors for progression," Headache: The Journal of Head and Face Pain, vol. 45, pp. S3-S13, 2005.

[65] D. Mozaffarian, E. J. Benjamin, A. S. Go et al., "Heart disease and stroke statistics-2016 update: a report from the american heart association," Circulation, p. CIR. 0000000000000350, 2015.
[66] W. H. Theodore, S. S. Spencer, S. Wiebe et al., "Epilepsy in north america: a report prepared under the auspices of the global campaign against epilepsy, the international bureau for epilepsy, the international league against epilepsy, and the world health organization," Epilepsia, vol. 47, no. 10, pp. 1700-1722, 2006.

[67] G. Y. Lim, W. W. Tam, Y. Lu, C. S. Ho, M. W. Zhang, and R. C. Ho, "Prevalence of depression in the community from 30 countries between 1994 and 2014," Scientific Reports, vol. 8, no. 1, p. 2861, 2018.

[68] G. Saposnik and O. H. D. Brutto, "Stroke in South America: a systematic review of incidence, prevalence, and stroke subtypes," Stroke, vol. 34, no. 9, pp. 2103-2107, 2003.

[69] A. J. Baxter, K. M. Scott, T. Vos, and H. A. Whiteford, "Global prevalence of anxiety disorders: a systematic review and metaregression," Psychological Medicine, vol. 43, no. 5, pp. 897-910, 2013.

[70] L. J. Stovner and C. Andree, "Prevalence of headache in europe: a review for the eurolight project," The Journal of Headache and Pain, vol. 11, no. 4, pp. 289-299, 2010.

[71] N. P. Şensöz, Ü. T. Börü, C. Bölük et al., "Stroke epidemiology in Karabük city Turkey: Community based study," eNeurologicalSci, vol. 10, pp. 12-15, 2018.

[72] M. d. de Rijk, C. Tzourio, M. M. Breteler et al., "Prevalence of parkinsonism and parkinson's disease in europe: the europarkinson collaborative study. european community concerted action on the epidemiology of parkinson's disease," Journal of Neurology, Neurosurgery \& Psychiatry, vol. 62, no. 1, pp. 10-15, 1997.

[73] E. Shao, J. Hughes, and R. Eley, "The presenting and prescribing patterns of migraine in an australian emergency department: a descriptive exploratory study," World Journal of Emergency Medicine, vol. 8, no. 3, p. 170, 2017.

[74] W. A. D. o. Health, Epidemiology Profile of Neurological Conditions in Western Australia, Health Strategy and Networks Branch, Australia, 2015.

[75] M. Bellon, R. J. Panelli, and F. Rillotta, "Epilepsy-related deaths: An Australian survey of the experiences and needs of people bereaved by epilepsy," Seizure, vol. 29, pp. 162-168, 2015.

[76] P. Mehta, A. Kifley, J. J. Wang, E. Rochtchina, P. Mitchell, and C. M. Sue, "Population prevalence and incidence of Parkinson's disease in an Australian community," Internal Medicine Journal, vol. 37, no. 12, pp. 812-814, 2007.

[77] M. Prince, R. Bryce, E. Albanese, A. Wimo, W. Ribeiro, and C. P. Ferri, "The global prevalence of dementia: a systematic review and metaanalysis," Alzheimer's \& Dementia, vol. 9, no. 1, Article ID e2, pp. 63-75, 2013.

[78] B. Ray, N. Paul, A. Hazra et al., "Prevalence, burden, and risk factors of migraine: a community-based study from eastern india," Neurology India, vol. 65, no. 6, pp. 1280-1288, 2017.

[79] M. I. khan, J. I. Khan, S. I. Ahmed, and U. U. Haq, "The epidemiology of stroke in a developing country (Pakistan)," Journal of Neurology \& Stroke, vol. 8, no. 1, 2018.

[80] H. Ebrahimi, M. Shafa, and S. H. Asl, "Prevalence of active epilepsy in kerman, iran: a house based survey," Acta Neurologica Taiwanica, vol. 21, no. 3, pp. 115-124, 2012.

[81] A. K. Verma, J. Raj, V. Sharma, T. B. Singh, S. Srivastava, and R. Srivastava, "Epidemiology and associated risk factors of parkinson's disease among the north indian population," Clinical Epidemiology and Global Health, vol. 5, no. 1, pp. 8-13, 2017. 
[82] P. S. Mathuranath, A. George, N. Ranjith et al., "Incidence of alzheimer's disease in india: a 10 yearsfollow-up study," Neurology India, vol. 60, no. 6, p. 625, 2012.

[83] S.-M. Fereshtehnejad, M. Shafieesabet, A. Rahmani, A. Delbari, and J. Lökk, "Medium-to-high prevalence of screening-detected parkinsonism in the urban area of Tehran, Iran: Data from a community-based door-to-door study," Neuropsychiatric Disease and Treatment, vol. 11, pp. 321-332, 2015.

[84] S. Gholamzadeh, B. Heshmati, A. Manni, P. Petramfar, and Z. Baghery, "The prevalence of Alzheimer's disease; its risk and protective factors among the elderly population in Iran," Shiraz E Medical Journal, vol. 18, no. 9, 2017.

[85] J. Ni, F. Han, J. Yuan et al., “The discrepancy of neurological diseases between china and western countries in recent two decades," Chinese Medical Journal, vol. 131, no. 8, pp. 886-891, 2018.

[86] L. J. Stovner, E. Nichols, T. J. Steiner et al., "Global, regional, and national burden of migraine and tension-type headache, 1990-2016: a systematic analysis for the global burden of disease study 2016," The Lancet Neurology, vol. 17, no. 11, pp. 954-976, 2018.

[87] V. L. Feigin, M. H. Forouzanfar, R. Krishnamurthi et al., "Global and regional burden of stroke during 1990-2010: findings from the global burden of disease study 2010," The Lancet, vol. 383, no. 9913, pp. 245-255, 2014.

[88] P. Ventevogel, W. van de Put, H. Faiz, B. van Mierlo, M. Siddiqi, and I. H. Komproe, "Improving access to mental health care and psychosocial support within a fragile context: a case study from afghanistan," PLoS Medicine, vol. 9, no. 5, p. e1001225, 2012.

[89] S.-M. Shin, H. J. Kim, L. Liw, and S. Kim, "Depression and PTSD in pashtun women in kandahar, afghanistan," Asian Nursing Research, vol. 3, no. 2, pp. 90-98, 2009.

[90] E. R. Dorsey, A. Elbaz, E. Nichols et al., "Global, regional, and national burden of parkinson's disease, 1990-2016: a systematic analysis for the global burden of disease study 2016," The Lancet Neurology, vol. 17, no. 11, pp. 939-953, 2018.

[91] G. Miller, "A battle no soldier wants to fight," American Association for the Advancement of Science, vol. 333, no. 6042, pp. 517-518, 2011.

[92] D. Santarsieri and T. L. Schwartz, "Antidepressant efficacy and side-effect burden: a quick guide for clinicians," Drugs in Context, vol. 4, 2015.

[93] J. M. Ferguson, "SSRI antidepressant medications: adverse effects and tolerability," Primary Care Companion to the Journal of Clinical Psychiatry, vol. 3, no. 1, pp. 22-27, 2001.

[94] A. F. Carvalho, M. S. Sharma, A. R. Brunoni, E. Vieta, and G. A. Fava, "The safety, tolerability and risks associated with the use of newer generation antidepressant drugs: a critical review of the literature," Psychotherapy and Psychosomatics, vol. 85, no. 5, pp. 270-288, 2016.

[95] C. E. Griffin III, A. M. Kaye, F. R. Bueno, and A. D. Kaye, "Benzodiazepine pharmacology and central nervous systemmediated effects," Ochsner Journal, vol. 13, no. 2, pp. 214-223, 2013.

[96] F. Batool, "Buspirone and anxiety disorders: a review with pharmacological and clinical perspectives," The Internet Journal of Pharmacology, vol. 5, no. 2, 2007.

[97] H. M. Kwon, J. W. Baek, S. P. Lee, and J. I. Cho, "A fatal adverse effect of barbiturate coma therapy: dyskalemia," Korean Journal of Neurotrauma, vol. 12, no. 2, pp. 156-158, 2016.
[98] F. Stella, M. Radanovic, P. R. Canineu, V. J. R. de Paula, and O. V. Forlenza, "Anti-dementia medications: current prescriptions in clinical practice and new agents in progress," Therapeutic Advances in Drug Safety, vol. 6, no. 4, pp. 151-165, 2015.

[99] Y.-J. Huang, C.-H. Lin, H.-Y. Lane, and G. E. Tsai, "NMDA neurotransmission dysfunction in behavioral and psychological symptoms of Alzheimer's disease," Current Neuropharmacology, vol. 10, no. 3, pp. 272-285, 2012.

[100] V. S. C. Fung, M. A. Hely, G. De Moore, and J. G. L. Morris, "Drugs for parkinson's disease," Australian Prescriber, vol. 24, no. 4, pp. 92-95, 2001.

[101] M. J. Brodie, "Sodium channel blockers in the treatment of epilepsy," CNS Drugs, vol. 31, no. 7, pp. 527-534, 2017.

[102] B. J. Kopecky, R. Liang, and J. Bao, "T-type calcium channel blockers as neuroprotective agents," Pflügers Archiv - European Journal of Physiology, vol. 466, no. 4, pp. 757-765, 2014.

[103] J. T. Lerner, N. Salamon, and R. Sankar, "Clinical profile of vigabatrin as monotherapy for treatment of infantile spasms," Neuropsychiatric Disease and Treatment, vol. 6, p. 731, 2010.

[104] R. Qureshi, M. Ilyas, G. Rahim, W. Ahmad, H. Shaheen, and K. Ullah, "Ethnobotanical study of bhera, district sargodha, pakistan," Archives Des Sciences, vol. 65, no. 11, pp. 690-707, 2012.

[105] T. A. Alamgeer, M. Rashid, M. N. H. Malik, and M. N. Mushtaq, "Ethnomedicinal survey of plants of valley alladand dehri, tehsil batkhela, district malakand, pakistan," International Journal of Basic Medical Sciences and Pharmacy (IJBMSP), vol. 3, no. 1, 2013.

[106] A. Shah, S. K. Marwat, and F. Gohar, "Ethnobotanical study of medicinal plants of semi-tribal area of Makerwal \&amp; Gulla Khel (lying between Khyber Pakhtunkhwa and Punjab Provinces), Pakistan," American Journal of Plant Sciences, vol. 4, no. 01, p. 98, 2013.

[107] I. Iqbal and M. Hamayun, "Studies on the traditional uses of plants of malam jabba valley, district swat, pakistan," Ethnobotanical Leaflets, vol. 2004, no. 1, p. 15, 2004.

[108] A. Hazrat, M. Nisar, J. Shah, and S. Ahmad, "Ethnobotanical study of some elite plants belonging to dir, kohistan valley, khyber pukhtunkhwa, pakistan," Pakistan Journal of Botany, vol. 43, no. 2, pp. 787-795, 2011.

[109] M. Haider and L. Zhong, "Ethno-medicinal uses of plants from district bahawalpur, pakistan," Current Research Journal of Biological Sciences, vol. 6, pp. 183-190, 2014.

[110] A. A. Shah, M. Ramzan, and R. Saba, "Ethnoecological studies of herbs and shrubs of miani sahib graveyard, lahore city, punjab, pakistan," Journal of Bioresource Management, vol. 3, no. 2, p. 5, 2016.

[111] A. B. Gulshan, A. A. Dasti, S. Hussain, M. I. Atta, and M. Aminud-Din, "Indigenous uses of medicinal plants in rural areas of dera ghazi khan, punjab, pakistan," Journal of Agricultural \& Biological Science, vol. 7, no. 9, pp. 750-762, 2012.

[112] S. S. Ahmad, "Medicinal wild plants from lahore-islamabad motorway (M-2)," Pakistan Journal of Botany, vol. 39, no. 2, pp. 355-375, 2007.

[113] M. Ajaib, Z. Khan, and A. Zikrea, "Ethnobotanical survey of some important herbaceous plants of district kotli, azad jammu \& kashmir," Biologia (Pakistan), vol. 60, no. 1, pp. 11-22, 2014.

[114] S. U. Khan, R. U. Khan, I. Ullah, S. Mehmood, A. Muhammad, and M. Ullah, "Morpho-anatomical study of selected plants of district bannu, khyber pakhtunkhwa, pakistan," Pakistan Journal of Weed Science Research, vol. 19, no. 4, pp. 447-464, 2013. 
[115] A. Noman, I. Hussain, Q. Ali, M. A. Ashraf, and M. Z. Haider, "Ethnobotanical studies of potential wild medicinal plants of ormara, gawadar, pakistan," Emirates Journal of Food and Agriculture, vol. 25, no. 10, pp. 751-759, 2013.

[116] M. R. Awan, Z. Jamal, and A. Khan, "Ethno-botanical studies of economically important plants from mountainous region of Gilgit-Baltistan," Science, Technology and Development, vol. 32, pp. 308-318, 2013.

[117] S. Z. Husain, R. N. Malik, M. Javaid, and S. Bibi, "Ethonobotanical properties and uses of medicinal plants of morgah biodiversity park, rawalpindi," Pakistan Journal of Botany, vol. 40, no. 5, pp. 1897-1911, 2008.

[118] A. Shah, S. Rahim, K. H. Bhatti et al., "Ethnobotanical study and conservation status of trees in the district sargodha, punjab, pakistan," Phyton, International Journal of Experimental Botany, vol. 84, no. 1, pp. 34-44, 2016.

[119] M. Umair, M. Altaf, and A. M. Abbasi, "An ethnobotanical survey of indigenous medicinal plants in hafizabad district, Punjab-Pakistan," PLoS ONE, vol. 12, no. 6, Article ID e0177912, 2017.

[120] H. Iqbal, Z. Sher, and Z. U. Khan, "Medicinal plants from salt range pind dadan khan, district jhelum, punjab, pakistan," Journal of Medicinal Plants Research, vol. 5, no. 11, pp. 2157-2168, 2011.

[121] W. Murad, A. Ahmad, G. Ishaq, M. S. Khan, M. A. H. Khan, and I. Ullah, "Ethnobotanical studies on plant resources of hazar nao forest, district malakand, pakistan," Pakistan Journal of Weed Science Research, vol. 18, no. 4, 2012.

[122] Z. I. Awan, H. Rehman, A. A. Awan, F. A. Minhas, and M. N. Khan, "Ethnobotanical importance of some highly medicinal plants of district muzaffarabad, pakistan with special reference to the species of the genus viburnum," IOSR Journal of Pharmacy and Biological Sciences, vol. 6, no. 2, pp. 53-66, 2013.

[123] A. M. Hussain, M. S. A. Abbasi, N. Hussain, and S. A. Majid, "A survey of important indigenous medicinal plants of district bhimber azad jammu \& kashmir, pakistan," International Journal of Advanced Research, vol. 1, pp. 635-644, 2013.

[124] M. F. Nisar, F. Jaleel, and S. M. Haider, "Exploration of ethno-medicinal plants and their ritual uses in bahawalnagar, pakistan," Middle-East Journal of Scientific Research, vol. 21, no. 9, pp. 1466-1471, 2014.

[125] A. T. Khalil, Z. K. Shinwari, M. Qaiser, and K. B. Marwat, "Phyto-therapeutic claims about euphorbeaceous plants belonging to pakistan; an ethnomedicinal review," Pakistan Journal of Botany, vol. 46, no. 3, pp. 1137-1144, 2014.

[126] S. M. Wazir, A. A. Dasti, and J. Shah, "Common medicinal plants of chapursan valley, gojal ii, gilgit-pakistan," Journal of Research (Science) Bahauddin Zakariya University, Multan, Pakistan, vol. 15, pp. 41-43, 2004.

[127] A. M. M. Kanwal, S. Shaukat, R. Javed, and R. Ilyas, "Exploration of ethnomedicinal values of imperative plants of district gujrat, pakistan," Middle-East Journal of Scientific Research, vol. 7, pp. 397-400, 2011.

[128] A. M. Sarangzai, A. Ahmed, and S. K. Laghari, "Traditional uses of some useful medicinal plants of ziarat district balochistan, pakistan," FUUAST Journal of Biology, vol. 3, no. 1, p. 101, 2013.

[129] A. Ghani, Z. Ali, and S. Perveen, "Folk recipes and ethno botanical survey of medicinal plants mianwali district (pakistan)," International Journal of Current Pharmaceutical Research, vol. 4, no. 2, pp. 61-63, 2012.
[130] Z. Sher, Z. U. D. Khan, and F. Hussain, "Ethnobotanical studies of some plants of chagharzai valley, district buner, pakistan," Pakistan Journal of Botany, vol. 43, no. 3, pp. 1445-1452, 2011.

[131] M. Shuaib and I. Khan, "Study of Medicinal Plants of Lower Dir, Timergara, Tehsil Balambat, Khyber Paktunkhaw-Pakistan," American-Eurasian Journal of Agricultural \& Environmental Sciences, vol. 2015., 15, p. 2088, 2088.

[132] I. Ahmad, M. Ibrar, Barkatullah, and N. Ali, "Ethnobotanical study of tehsil kabal, swat district, KPK, pakistan," Journal of Botany, vol. 2011, Article ID 368572, 9 pages, 2011.

[133] M. Ilyas, R. Qureshi, Z. K. Shinwari, M. Arshad, S. N. Mirza, and Zia-Ul-Haq, "Some ethnoecological aspects of the plants of qalagai hills, kabal valley, swat, pakistan," International Journal of Agriculture and Biology, vol. 15, no. 5, pp. 801-810, 2013.

[134] N. Ahmad, S. Anwar, H. Fazal, and B. H. Abbasi, "Medicinal plants used in indigenous herapy by people of madyan valley in district swat, pakistan," International Journal of Medicinal and Aromatic Plants, vol. 3, no. 1, pp. 47-54, 2013.

[135] F. Haq, H. Ahmad, and M. Alam, “Traditional uses of medicinal plants of nandiar khuwarr catchment (district battagram), pakistan," Journal of Medicinal Plants Research, vol. 5, no. 1, pp. 39-48, 2011.

[136] R. A. Qureshi and M. A. Ghufran, "Indigenous knowledge of selected medicinal wild plants of district attock, punjab, pakistan," Pakistan Journal of Botany, vol. 39, pp. 2291-2299., 2007.

[137] N. B. Chauhan and J. Sandoval, "Amelioration of early cognitive deficits by aged garlic extract in alzheimer's transgenic mice," Phytotherapy Research, vol. 21, no. 7, pp. 629-640, 2007.

[138] D. Dhingra and V. Kumar, "Evidences for the involvement of monoaminergic and GABAergic systems in antidepressant-like activity of garlic extract in mice," Indian Journal of Pharmacology, vol. 40, no. 4, pp. 175-179, 2008.

[139] U. Advani, A. Ansari, and E. Menghani, "Anticonvulsant potentials of sesamum indicum and allium sativum oil alone and in combination in animal models," International Journal of Pharmacy and Pharmaceutical Sciences, vol. 3, 4, pp. 154-158, 2011.

[140] N. Martins, S. Petropoulos, and I. C. F. R. Ferreira, "Chemical composition and bioactive compounds of garlic (Allium sativum L.) as affected by pre- and post-harvest conditions: A review," Food Chemistry, vol. 211, pp. 41-50, 2016.

[141] P. Jain, H. P. Sharma, F. Basri, K. Priya, and P. Singh, "Phytochemical analysis of bacopa monnieri (L.) wettst. and their antifungal activities," Indian Journal of Traditional Knowledge, vol. 16, no. 2, pp. 310-318, 2017.

[142] E. B. Russo, "Taming THC: potential cannabis synergy and phytocannabinoid-terpenoid entourage effects," British Journal of Pharmacology, vol. 163, no. 7, pp. 1344-1364, 2011.

[143] B. S. Audu, P. C. Ofojekwu, A. Ujah, and M. N. O. Ajima, "Phytochemical, proximate composition, amino acid profile and characterization of marijuana (cannabis sativa L.)," The Journal of Phytopharmacology, vol. 3, no. 1, pp. 35-43, 2014.

[144] H. M. Reza, H. Mohammad, E. Golnaz, and S. Gholamreza, "Effect of methanolic extract of hyoscymus niger L. on the seizure induced by picritoxin in mice," Pakistan Journal of Pharmaceutical Sciences, vol. 22, no. 3, pp. 308-312, 2009.

[145] J. Li, J. Shi, X.-W. Yu et al., "Chemical and pharmacological researches on Hyoscyamus niger," Chinese Herbal Medicine, vol. 3, pp. 117-126, 2011. 
[146] T. Sengupta, J. Vinayagam, N. Nagashayana, B. Gowda, P. Jaisankar, and K. P. Mohanakumar, "Antiparkinsonian effects of aqueous methanolic extract of Hyoscyamus niger seeds result from its monoamine oxidase inhibitory and hydroxyl radical scavenging potency," Neurochemical Research, vol. 36, no. 1, pp. 177-186, 2011.

[147] J. Talairach and P. Thournoux, Co-Planar Stereotaxic Atlas of the Human Brain, Thieme Medical Publishers, Stuttgart, Germany, 1988.

[148] K. Aparna, A. Joshi, and M. Vyas, "Adverse reaction of Parasika Yavani (Hyoscyamus niger Linn): Two case study reports," $A Y U$ (An International Quarterly Journal of Research in Ayurveda), vol. 36, no. 2, p. 174, 2015.

[149] R. M. Perez G., J. A. Perez L., L. M. Garcia D., and H. Sossa M., "Neuropharmacological activity of Solanum nigrum fruit," Journal of Ethnopharmacology, vol. 62, no. 1, pp. 43-48, 1998.

[150] N. N. Wannang, J. A. Anuka, H. O. Kwanashie, S. S. Gyang, and A. Auta, "Anti-seizure activity of the aqueous leaf extract of Solanum nigrum Linn. (solanaceae) in experimental animals," African Health Sciences, vol. 8, no. 2, pp. 74-79, 2008.

[151] Y. Zhao, F. Liu, and H.-X. Lou, "[Studies on the chemical constituents of Solanum nigrum].," Zhong yao cai $=$ Zhongyaocai $=$ Journal of Chinese medicinal materials, vol. 33, no. 4, pp. 555556, 2010.

[152] M. A. B. Nyeem, "Solanum nigrum (Maku): A review of pharmacological activities and clinical effects," IJAR, vol. 3, no. 1, pp. 12-17, 2017.

[153] S. C. Kaul and R. Wadhwa, Science of Ashwagandha: Preventive and Therapeutic Potentials, Springer International Publishing, Cham, 2017.

[154] W.-H. Peng, M.-T. Hsieh, Y.-S. Lee, Y.-C. Lin, and J. Liao, "Anxiolytic effect of seed of Ziziphus jujuba in mouse models of anxiety," Journal of Ethnopharmacology, vol. 72, no. 3, pp. 435441, 2000.

[155] J.-G. Jiang, X.-J. Huang, and J. Chen, "Comparison of the sedative and hypnotic effects of flavonoids, saponins, and polysaccharides extracted from Semen Ziziphus Jujube," Natural Product Research (Formerly Natural Product Letters), vol. 21, no. 4, pp. 310-320, 2007.

[156] M. Pahuja, J. Mehla, K. H. Reeta, S. Joshi, and Y. K. Gupta, "Hydroalcoholic extract of Zizyphus jujuba ameliorates seizures, oxidative stress, and cognitive impairment in experimental models of epilepsy in rats," Epilepsy \& Behavior, vol. 21, no. 4, pp. 356-363, 2011.

[157] S. Kumaravel and K. Alagusundaram, "Antimicrobial activity and Phytochemical analysis of selected Indian spices," Journal of Pure and Applied Microbiology, vol. 8, no. 5, pp. 4131-4136, 2014.

[158] R. Sabbaghzadeh and M. Asadbegi, "Effects of Methanolic extracts of Papaver Somniferum on Picrotoxin induced seizure in mice," Advances in Environmental Biology, vol. 8, no. 10, pp. 740-743, 2014.

[159] I. Rayment, H. M. Holden, M. Whittaker et al., "Structure of the actin-myosin complex and its implications for muscle contraction," Science, vol. 261, no. 5117, pp. 58-65, 1993.

[160] S. Wang, J. Zhang, Z. Zhang et al., "Identification of chemical constituents in the extract and rat serum from Ziziphus Jujuba mill. By HPLC-PDA-ESI-MSn," Iranian Journal of Pharmaceutical Research, vol. 13, no. 3, pp. 1055-1064, 2014.

[161] Z. Wang, D. Zhang, S. Hui, Y. Zhang, and S. Hu, "Effect of tribulus terrestris saponins on behavior and neuroendocrine in chronic mild stress depression rats," Journal of Traditional Chinese Medicine, vol. 33, no. 2, pp. 228-232, 2013.

[162] S. Ahmed, S. Lutfullah, I. Ahmed, R. Farooq, and J. Iqbal, "Anxiolytic activity of Tribulus terrestris on elevated plus maze," Journal of Applied Pharmaceutical Science, vol. 4, no. 2, pp. 126 128, 2014.

[163] S. Chhatre, T. Nesari, G. Somani, D. Kanchan, and S. Sathaye, "Phytopharmacological overview of Tribulus terrestris," Pharmacognosy Reviews, vol. 8, no. 15, pp. 45-51, 2014.

[164] O. A. Phillips, K. T. Mathew, and M. A. Oriowo, "Antihypertensive and vasodilator effects of methanolic and aqueous extracts of Tribulus terrestris in rats," Journal of Ethnopharmacology, vol. 104, no. 3, pp. 351-355, 2006.

[165] V. S. Kasture, C. T. Chopde, and V. K. Deshmukh, "Anticonvulsive activity of Albizzia lebbeck, Hibiscus rosa sinesis and Butea monosperma in experimental animals," Journal of Ethnopharmacology, vol. 71, no. 1-2, pp. 65-75, 2000.

[166] H. D. Une, V. P. Sarveiya, S. C. Pal, V. S. Kasture, and S. B. Kasture, "Nootropic and anxiolytic activity of saponins of Albizzia lebbeck leaves," Pharmacology Biochemistry \& Behavior, vol. 69, no. 3-4, pp. 439-444, 2001.

[167] V. Padamanabhan, M. Ganapathy, and V. K. Evanjelene, "Preliminary phytochemical and anti-bacterial studies on flowers and pods of Albizia lebbeck (Benth)," International Journal of Emerging Technology and Advanced Engineering, vol. 3, no. 9, pp. 541-544, 2013.

[168] S. Desai, P. Tatke, and S. Gabhe, "Isolation of catechin from stem bark of Albizia lebbeck," International Journal of Analytical, Pharmaceutical and Biomedical Sciences, vol. 3, no. 2, pp. 31-35, 2014.

[169] R. Singh, S. De, and A. Belkheir, "Avena sativa (oat), a potential neutraceutical and therapeutic agent: an overview," Critical Reviews in Food Science and Nutrition, vol. 53, no. 2, pp. 126144, 2013

[170] K. Usha Rani, M. Ramaiah, K. Nagaphani, V. Preethi, and M. Srinadh, "Screening for antidepressant-like effect of methanolic seed extract of Avena sativa using animal models," Pharmacognosy Journal, vol. 6, no. 3, pp. 86-92, 2014.

[171] D. Kaur, A. Kamboj, and R. Shri, "Comparative evaluation of anxiolytic effects of various extracts of oats (Avena sativa), rice bran (Oryza sativa) and spinach (Spinacia oleracea) in experimental animals," International Journal of Pharmaceutical Sciences and Research, vol. 7, no. 10, p. 4110, 2016.

[172] M. Goyal, B. P. Nagori, and D. Sasmal, "Sedative and anticonvulsant effects of an alcoholic extract of Capparis decidua," Journal of Natural Medicines, vol. 63, no. 4, pp. 375-379, 2009.

[173] P. D. Verma, R. D. Dangar, K. N. Shah, D. M. Gandhi, and B. N. Suhagia, "Pharmacognostical potential of Capparis decidua Edgew," Journal of Applied Pharmaceutical Science, vol. 1, no. 10, pp. 6-11, 2011.

[174] L. M. Campêlo, S. G. Lima, C. M. Feitosa, and R. M. Freitas, "Evaluation of central nervous system effects of Citrus limon essential oil in mice," Revista Brasileira de Farmacognosia, vol. 21, no. 4, pp. 668-673, 2011.

[175] L. M. Lopes Campêlo, C. Gonçalves e Sá, A. A. C. de Almeida et al., "Sedative, anxiolytic and antidepressant activities of Citrus limon (Burn) essential oil in mice," Die Pharmazie-An International Journal of Pharmaceutical Sciences, vol. 66, no. 8, pp. 623-627, 2011.

[176] A. Ben Hsouna, N. Ben Halima, S. Smaoui, and N. Hamdi, "Citrus lemon essential oil: Chemical composition, antioxidant 
and antimicrobial activities with its preservative effect against Listeria monocytogenes inoculated in minced beef meat," Lipids in Health and Disease, vol. 16, no. 1, 2017.

[177] S. Najafi, N. Sanadgol, B. S. Nejad, M. A. Beiragi, and E. Sanadgol, "Phytochemical screening and antibacterial activity of Citrullus colocynthis (Linn.) schrad against Staphylococcus aureus," Journal of Medicinal Plants Research, vol. 4, no. 22, pp. 2321-2325, 2010.

[178] V. Kumar, S. K. Sharma, K. Nagarajan, and P. K. Dixit, "Effects of lycopene and sodium valproate on pentylenetetrazol-induced kindling in mice," Iranian Journal of Medical Sciences, vol. 41, no. 5, pp. 430-436, 2016.

[179] K. Gokul, “Oral supplements of aqueous extract of tomato seeds alleviate motor abnormality, oxidative impairments and neurotoxicity induced by rotenone in mice: relevance to Parkinson's disease," Neurochemical Research, vol. 39, no. 7, pp. 1382-1394, 2014.

[180] J. Bae, M. Han, H. Shin et al., "Lycopersicon esculentum extract enhances cognitive function and hippocampal neurogenesis in aged mice," Nutrients, vol. 8, no. 11, p. 679, 2016.

[181] J. S. Oliveira, L. A. Porto, and C. S. Estevam, "Phytochemical screening and anticonvulsant property of Ocimum basilicum leaf essential oil," Boletín Latinoamericano y del Caribe de Plantas Medicinales y Aromáticas, vol. 8, no. 3, 2009.

[182] S. Sarahroodi, S. Esmaeili, Z. Hemmati, P. Mikaili, and Y. Saberi, "The effects of green Ocimum basilicum hydroalcoholic extract on retention and retrieval of memory in mice," Ancient Science of Life, vol. 31, no. 4, p. 185, 2012.

[183] M. Rabbani, S. E. Sajjadi, and A. Vaezi, "Evaluation of anxiolytic and sedative effect of essential oil and hydroalcoholic extract of Ocimum basilicum L. and chemical composition of its essential oil," Research in Pharmaceutical Sciences, vol. 10, no. 6, pp. 535543, 2015.

[184] S. S. Ali, M. G. Abd El Wahab, N. N. Ayuob, and M. Suliaman, "The antidepressant-like effect of Ocimum basilicum in an animal model of depression," Biotechnic \& Histochemistry, vol. 92, no. 6, pp. 390-401, 2017.

[185] S. Adiga, P. Trivedi, V. Ravichandra, D. Deb, and F. Mehta, "Effect of Punica granatum peel extract on learning and memory in rats," Asian Pacific Journal of Tropical Medicine, vol. 3, no. 9, pp. 687-690, 2010.

[186] S. Das and P. Sarma, "A study on the anticonvulsant and antianxiety activity of ethanolic extract of punica granatum linn," International Journal of Pharmacy and Pharmaceutical Sciences, vol. 6, no. 2, pp. 389-392, 2014.

[187] T. Yuan, H. Ma, W. Liu et al., "Pomegranate's neuroprotective effects against alzheimer's disease are mediated by urolithins, its ellagitannin-gut microbial derived metabolites," ACS Chemical Neuroscience, vol. 7, no. 1, pp. 26-33, 2015.

[188] R. Shastry, A. Sharma, V. Sayeli, and U. S. Dinkar, "Screening of antidepressant activity of punica granatum in mice," Pharmacognosy Journal, vol. 9, no. 1, pp. 27-29, 2017.

[189] J. Wise, "FDA approves its first cannabis based medicine," British Medical Journal Publishing Group, 2018.

[190] A. G. Atanasov, B. Waltenberger, E. M. Pferschy-Wenzig et al., "Discovery and resupply of pharmacologically active plantderived natural products: a review," Biotechnology Advances, vol. 33, no. 8, pp. 1582-1614, 2015.

[191] N. Brondino, S. Re, and A. Boldrini, "Curcumin as a therapeutic agent in dementia: a mini systematic review of human studies," The Scientific World Journal, vol. 2014, Article ID 174282, 6 pages, 2014.
[192] N. Gurnani, D. Mehta, M. Gupta, and B. k. Mehta, "Natural Products: source of potential drugs," African Journal of Basic \& Applied Sciences, vol. 6, pp. 171-186, 2014.

[193] S. Girdhar, A. Girdhar, S. K. Verma, V. Lather, and D. Pandita, "Plant derived alkaloids in major neurodegenerative diseases: from animal models to clinical trials," Journal of Ayurvedic and Herbal Medicine, vol. 1, no. 3, pp. 91-100, 2015.

[194] C. Sawda, C. Moussa, and R. S. Turner, "Resveratrol for alzheimer's disease," Annals of the New York Academy of Sciences, vol. 1403, no. 1, pp. 142-149, 2017.

[195] M. S. Rafii, B. G. Skotko, M. E. McDonough et al., "A randomized, double-blind, placebo-controlled, phase II study of oral ELND005 (scyllo -inositol) in young adults with down syndrome without dementia," Journal of Alzheimer's Disease, vol. 58, no. 2, pp. 401-411, 2017. 


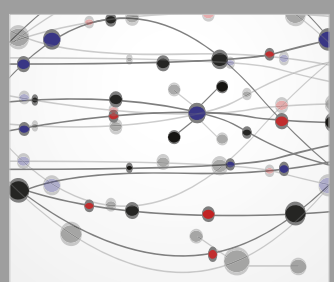

The Scientific World Journal
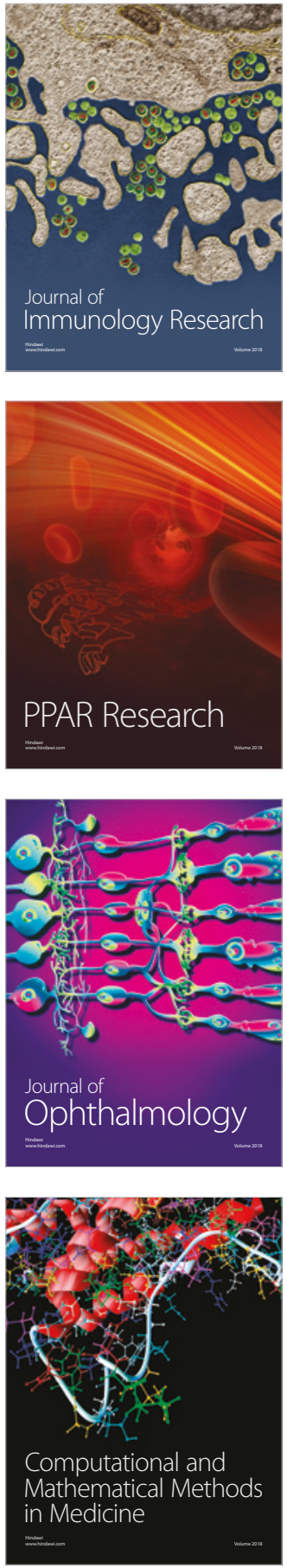

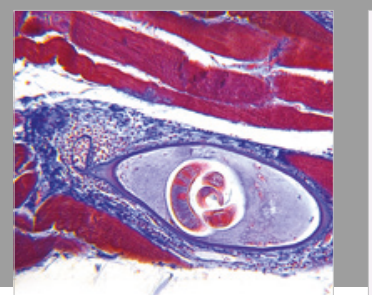

Gastroenterology Research and Practice

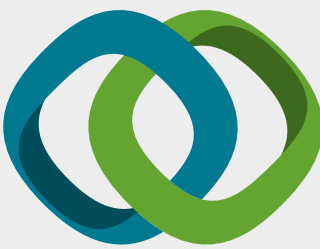

\section{Hindawi}

Submit your manuscripts at

www.hindawi.com
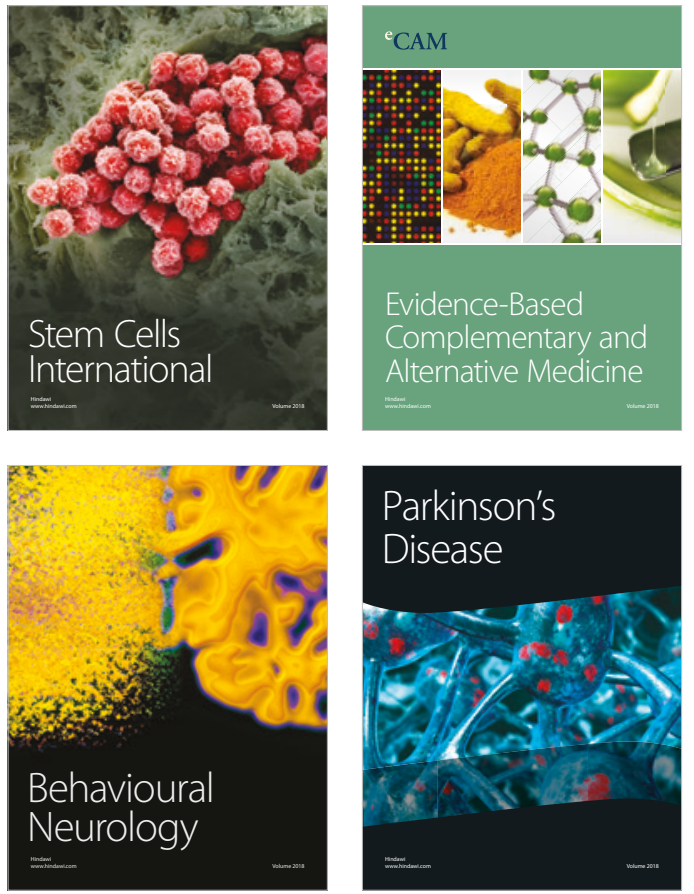

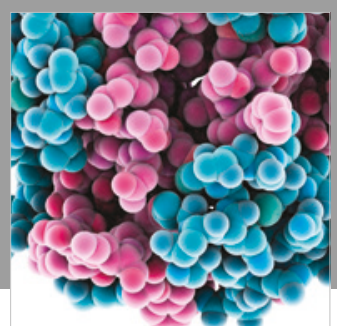

ournal of

Diabetes Research

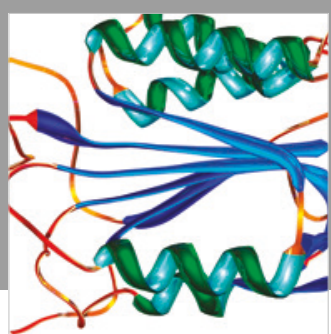

Disease Markers
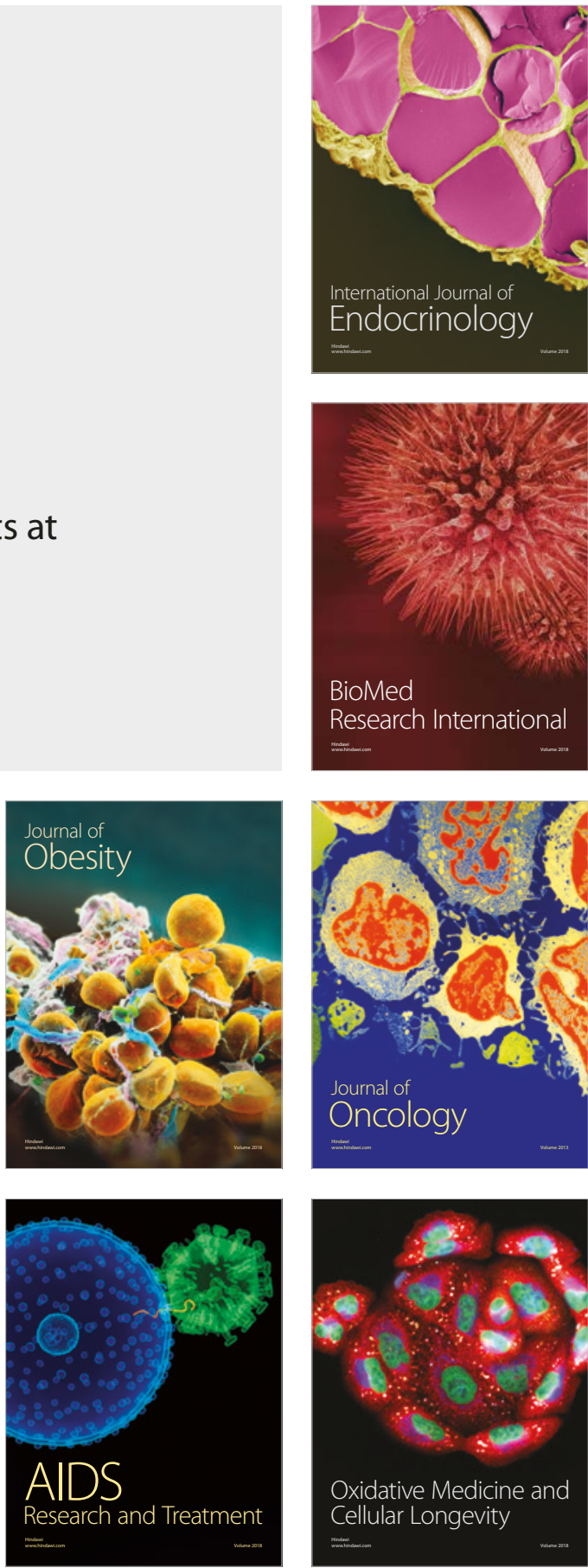